\title{
Isotopic variations with distance and time in the volcanic islands of the Cameroon line: evidence for a mantle plume origin
}

\author{
Der-Chuen Lee ${ }^{\text {a }}$, Alex N. Halliday ${ }^{\mathrm{a}}$, J. Godfrey Fitton ${ }^{\mathrm{b}}$, Giampero Poli ${ }^{\mathrm{c}}$ \\ ${ }^{a}$ Department of Geological Sciences, University of Michigan, 1006 C.C. Little Building, Ann Arbor, MI 48109-1063, USA \\ ${ }^{b}$ Department of Geology and Geophysics, Unicersity of Edinburgh, Edinburgh, EH9 3JW, UK \\ ${ }^{c}$ Department of Earth Science, University of Perugia, I-06100 Perugia, Italy
}

(Received August 30, 1993; revision accepted March 25, 1994)

\begin{abstract}
The oceanic sector of the Cameroon line consists of three volcanic islands: Principe, São Tomé and Pagalu. New ${ }^{40} \mathrm{Ar}-{ }^{39} \mathrm{Ar}$ data for Pagalu basalts, combined with published $\mathrm{K}-\mathrm{Ar}$ ages for Principe and São Tomé, indicate that all three islands have been active in the past $5 \mathrm{Ma}$. They have similar petrogenetic histories, with basements of basaltic flows capped by more evolved rocks. However, the age of the earliest exposed volcanic rocks decreases oceanward from Principe ( $31 \mathrm{Ma}$ ) to São Tomé (13 Ma) to Pagalu (4.8 Ma). This age progression is consistent with the suggested motion of the African plate over this period of time. The average incompatible trace element compositions of $<10$ Ma lavas with $\geqslant 4 \mathrm{wt} \% \mathrm{MgO}$ on each island are very similar. However, $\left({ }^{87} \mathrm{Sr} /{ }^{86} \mathrm{Sr}\right)$ increases from 0.7029 to 0.7037 and $\left({ }^{206} \mathrm{~Pb} /{ }^{204} \mathrm{~Pb}\right)_{\mathrm{t}}$ decreases from 20.2 to 18.9 from Principe through São Tomé to Pagalu for all samples younger than $10 \mathrm{Ma}$. In addition to the overall spatial isotopic variations, Principe and Sāo Tomé display temporal isotopic variations, with $\mathrm{Pb}$ isotopic ratios becoming progressively more radiogenic. Pagalu shows no temporal geochemical or isotopic differences and the island has the least radiogenic $\mathrm{Pb}$ but most radiogenic $\mathrm{Sr}$. These distinctive $\mathrm{Pb}, \mathrm{Sr}$ and $\mathrm{Nd}$ isotopic compositions are also found in the early tholeiitic hyaloclastite breccia from Principe (31 Ma). Similarly, the $\mathrm{Nd}$ and $\mathrm{Sr}$ isotopic compositions are identical to those of the earliest São Tomé lavas (13 $\mathrm{Ma})$ and the $\mathrm{Pb}$ isotopic compositions of early Sáo Tomé samples are only slightly radiogenic relative to Pagalu. Therefore, it is probable that all these islands were initiated from a common source, similar to that of Pagalu, that migrated relative to the melt zone of each island with time. Since their initiation, the magma conduits at Principe and São Tomé have been gradually modified by the introduction of a HIMU component. The common source from which the islands were initially derived probably represents ambient upper mantle, entrained with the plume head during ascent. This entrained component is like 'PREMA', but the $\mathrm{Nd}$ and $\mathrm{Sr}$ isotopic data indicate that it represents variably mixed depleted and enriched components, such as DMM and EMI. The HIMU component is probably representative of a lower mantle source from which the plume head was derived. The long-lived episodic magmatism on Principe provides evidence that the initial melt migration paths from the upper mantle form a hot zone that can be re-activated after long periods $\left(10^{7} \mathrm{yr}\right)$ of apparent quiescence. The progression to HIMU characteristics within each island probably reflects the gradual flattening of the contaminated plume head within this hot zone, near the base of the lithosphere, and the melting of a stem composed of relatively uncontaminated HIMU mantle.
\end{abstract}




\section{Introduction}

The Cameroon line has been active for at least 65 myr and is currently defined by a $1600 \mathrm{~km}$ long, Y-shaped chain of intraplate volcanic centers, extending from the Atlantic island of Pagalu inland to west Africa. Young basaltic lavas are compositionally identical in oceanic and continental sectors, providing evidence that the lavas have been derived from sublithospheric depths [1]. However, rocks from the continent/ocean boundary region, as represented by the island of Bioko and the continental volcanic centers of Etinde and Mt. Cameroon, have relatively radio-

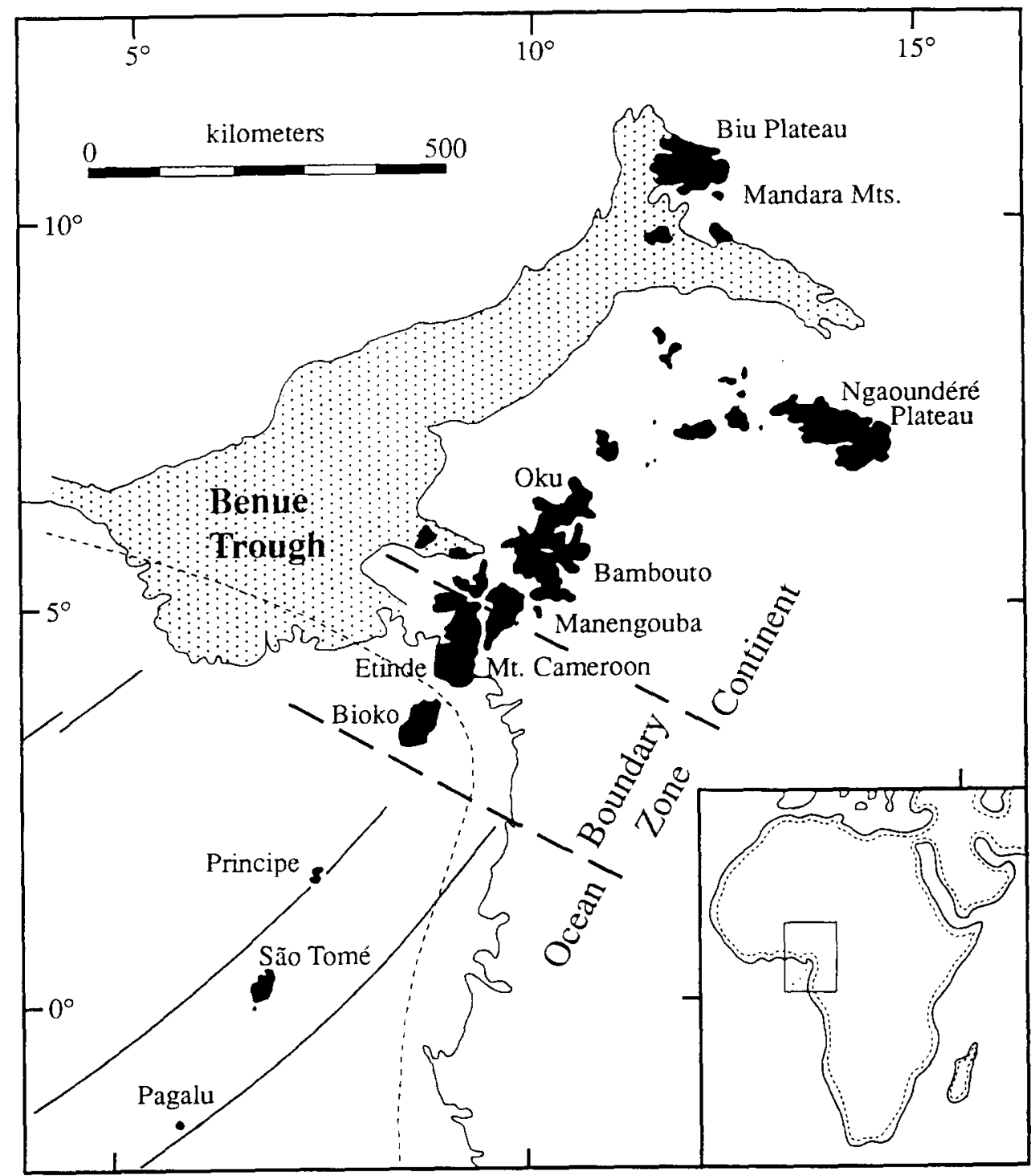

Fig. 1. Geological map showing the major Cenozoic volcanic centers of the Cameroon line and the Gulf of Guinea [adapted from 2]. The boundary between the continental and oceanic crust (thin broken line) and the oceanic transform faults are taken from Emery and Uchupi [51] and Sibuet and Mascle [52], respectively. 
genic $\mathrm{Pb}$ : there is a systematic decrease in ${ }^{206} \mathrm{~Pb} /$ ${ }^{204} \mathrm{~Pb}$ and ${ }^{208} \mathrm{~Pb} /{ }^{204} \mathrm{~Pb}$ from the continent/ocean boundary (c.o.b.) toward either end of the volcanic chain [2]. This has been explained in terms of the remelting of an enriched fossil plume head located beneath the site of continental break up in the present Gulf of Guinea. This model, however, provides no mechanism for remelting and does not explain the long-lived nature of magmatism along this lineament. The ocean islands of Principe, Sāo Tomé and Pagalu exhibit episodic and protracted volcanic histories (e.g., over 30 myr for Principe [3]). These most oceanward islands, located away from both the continent/ ocean boundary and the effects of crustal contamination that may complicate interpretations of data from the continental sector, provide an ideal location for studying changes in source composition with time in the Cameroon line.

Isotopic variations in MORB and OIB are generally attributed to mixing of several distinct components in the mantle. It has been suggested that a minimum of four mantle end-members are required to generate the observed isotopic variations in OIB [4-7]. Long-lived ocean island chains offer the opportunity to study how these components are incorporated into the source regions of OIB with time. The Hawaiian island chain is the classic example of a chain of OIB volcanoes originating from a hotspot. Many studies have shown that temporal isotopic variations exist within individual Hawaiian volcanic centers [8-13]. Similarly, the Samoan islands display an increase in $\mathrm{Sr}$ with decreases in $\mathrm{Nd}$ and $\mathrm{Pb}$ isotopic ratios westwards along the island chain [14,15], although White and Hofmann [16] have argued that these variations are not systematic. The Canary Islands display a systematic correlation between major elements and isotopic compositions, which are attributed to the assimilation of shallow enriched mantle components during differentiation $[17,18]$. However, no temporal isotopic variation is found in the Canary Islands. The Cameroon line has not been explicable by hotspot models because there has been no systematic migration in the inception of volcanism with time, as deduced from published isotopic ages. Furthermore, the individual centers have continued to be active for very long periods at the same time as the African plate has undergone considerable rotation. This study provides new geochronological data and trace element and $\mathrm{Sr}-\mathrm{Nd}-\mathrm{Pb}$ isotopic compositions for predominantly basaltic rocks from Pagalu, São Tomé and Principe. It is found that the source regions have migrated laterally relative to the volcanic centers through time, providing the first evidence for an active mantle plume origin for the magmatism of the Cameroon line.

\section{General geology}

The geology, petrology and geochronology of the Cameroon line have been reviewed elsewhere $[1,19-21]$, so only a brief summary is given here. There are at least 17 plutonic complexes, all in the continental sector, ranging in age from 65 to $30 \mathrm{Ma}$. Only a few of them have been studied with modern isotope geochemistry and the available data indicate that these plutonic complexes were primarily of mantle origin but contaminated by crustal components [22-24]. In addition, there are 12 major volcanic centers extending into the oceanic sector (Fig. 1), ranging in age from $35 \mathrm{Ma}$ to the present. The only currently active volcano is Mt. Cameroon [25,26], which erupted last in 1982, situated on the boundary between the oceanic and the continental sectors of the volcanic chain. Basic lavas, ranging in composition from basanite to hy-norm basalt, are present in all the volcanic centers except for Etinde, which is composed entirely of nephelinite. The evolved rocks in the continental volcanic centers comprise trachyte, trachyphonolite, rhyolite and rare phonolite. In Manengouba, evolved magmas form a complete compositional continuum with the basic lavas. However, other centers, such as Bambouto and $\mathrm{Oku}$, are strongly bimodal. Two basaltic plateaus (Ngaoundéré and Biu) mark the continental ends of the Y-shaped volcanic chain. The Mandara mountains include some of the oldest continental volcanic rocks on the Cameroon line. Basaltic lavas from the oceanic sector are compositionally similar to those of the continental sector [1], but trachytes are rare and rhyolite is 
absent. Phonolites are found on Principe and São Tomé.

Several models have been proposed to explain the origin of the Cameroon line. These include membrane tectonics [27], a hotspot [28,29] and rejuvenation of a fracture zone [30]. The membrane stress model is in conflict with the fact that the region would have been under compression, instead of extension, during the emplacement of the plutonic complexes. The lack of systematic progression in the published ages of volcanism for the Cameroon line [1] appears to rule out the conventional hotspot model. The fracture zone model does not offer any explanation for the cause of partial melting in the mantle. Fitton and Dunlop [1] suggested that the Cameroon line lavas originated from an upwelling asthenospheric hot zone which was emplaced underneath the Benue Trough, but became displaced relative to the lithosphere by the rotation of the African plate, and has been located beneath the Cameroon line and the Gulf of Guinea since the Cretaceous.

\section{Methods}

Major and trace elements were measured by $\mathrm{XRF}$ at the University of Edinburgh. For isotopic analyses, roughly $30 \mathrm{mg}$ of each sample was dissolved and, when necessary, about $15 \%$ of the solution was spiked for isotope dilution work. The separation of $\mathrm{Pb}$ and $\mathrm{U}$ was achieved with $\mathrm{HBr}$ and $\mathrm{HNO}_{3}$ chemistry, respectively, using roughly $0.3 \mathrm{ml}$ of $\mathrm{AG}-1 \times 8$ anion resin. The remaining solution was used for further separations. $\mathrm{Rb}, \mathrm{Sr}$ and the bulk REE were separated using $3 \mathrm{ml}$ of AG50W $\times 8$ cation resin, while $\mathrm{Sm}$ and $\mathrm{Nd}$ were separated using a $3 \mathrm{ml}$ column of PTFE coated with H-DEHP. Three mixed spikes were used for isotope dilution analyses: ${ }^{235} \mathrm{U}-$ ${ }^{208} \mathrm{~Pb},{ }^{87} \mathrm{Rb}-{ }^{84} \mathrm{Sr}$ and ${ }^{149} \mathrm{Sm}-{ }^{150} \mathrm{Nd}$. The total procedural blanks for $\mathrm{Pb}, \mathrm{Sr}$ and $\mathrm{Nd}$ were typically 150,70 and $25 \mathrm{pg}$ at the time when these samples were analyzed; insignificant for $\mathrm{Sr}$ and $\mathrm{Nd}$ and generally smaller than $0.3 \%$ for $\mathrm{Pb}$. All the isotopic measurements were made on two $\mathrm{VG}$
Sector thermal ionization mass spectrometers equipped with 6 and 7 Faraday collectors, respectively. $\mathrm{Nd}$ and $\mathrm{Sr}$ isotopic compositions were measured in multi-dynamic mode. We obtained $0.710245 \pm 10(2 \sigma, n=20)$ for the ${ }^{87} \mathrm{Sr} /{ }^{86} \mathrm{Sr}$ of NIST standard SRM 987, and $0.511850 \pm 10(2 \sigma$, $n=20$ ) for the ${ }^{143} \mathrm{Nd} /{ }^{144} \mathrm{Nd}$ of La Jolla $\mathrm{Nd}$ at the time of these analyses. $\mathrm{Pb}$ isotope ratios and all isotope dilution measurements were made using static multi-collection. All $\mathrm{Pb}$ analyses were corrected for fractionation and mass discrimination ( $0.1 \%$ per a.m.u. in this case) based on replicate analyses of NIST standard SRM 981. Our longterm reproducibility for ${ }^{206} \mathrm{~Pb} /{ }^{204} \mathrm{~Pb},{ }^{207} \mathrm{~Pb} /{ }^{204} \mathrm{~Pb}$ and ${ }^{208} \mathrm{~Pb} /{ }^{204} \mathrm{~Pb}$ is better than $0.1 \%$. A recent problem with $\mathrm{Pb}$ reproducibility is thought to have been associated with a fault on one Faraday collector [see 31]. This has been rectified. Duplication (total process) for 6 samples are presented in Table 2. The average difference for the 18 ratios duplicated is $0.05 \%$. The initial ${ }^{208} \mathrm{~Pb} /{ }^{204} \mathrm{~Pb}$ of samples in this study were calculated assuming $\mathrm{Th} / \mathrm{U}=4.0$, since isotope dilution of $\mathrm{Th}$ is not available and XRF Th data are generally poor. This simplification introduces negligible uncertainty to the initial $\mathrm{Pb}$ isotopic compositions.

All ${ }^{40} \mathrm{Ar}-{ }^{39} \mathrm{Ar}$ incremental heating analyses were performed at the University of Michigan. Basalt chips, roughly $4 \mathrm{~mm}$ in size, were washed with de-ionized $\mathrm{H}_{2} \mathrm{O}$ and acetone then dried. About $100 \mathrm{mg}$ of each sample was used, along with Fish Canyon Tuff biotite (with an age of 27.9 $\mathrm{Ma}$, which was cross-calibrated with a second standard Mmhb-1 with an age of $520.4 \mathrm{Ma}$ ), as the standard for determining the $J$ factor. The samples were irradiated at the Phoenix Memorial Reactor at the University of Michigan for $2 \mathrm{~h}$ with $2 \mathrm{MW}$ operating power. Samples were placed individually into a Ta furnace and heated incrementally for 10-12 steps, with each step lasting $20 \mathrm{~min}$. The released Ar was cleaned with hot Ti and SAES GP50-W getters before being released into a MAP 215 mass spectrometer equipped with a Faraday collector and an electron multiplier. The apparent age for individual steps was calculated from the measured ${ }^{40} \mathrm{Ar} /{ }^{39} \mathrm{Ar}$ after correction for background and interfering isotopes generated by neutron irradiation. 


\section{Petrology and geochronology of the oceanic sector of the Cameroon line}

There are four volcanic islands in the Cameroon line: Bioko, Principe, São Tomé and Pagalu (Fig. 1). Bioko is a young volcanic island consisting entirely of basaltic lavas, ranging from basanite to hy basalts. The island was included in the continent/ocean boundary (c.o.b.) zone by Halliday et al. [2,32], along with Etinde and Mt. Cameroon. These three volcanic centers are located at the seismically determined continent-ocean boundary and have similar isotopic compositions [32]. Therefore, this study is focused just on Principe, São Tomé and Pagalu.

\subsection{Principe}

Principe is a small, deeply eroded island measuring roughly $20 \times 15 \mathrm{~km}$. The petrology and $\mathrm{K}-\mathrm{Ar}$ geochronology of the island have been described by Fitton and Hughes [33] and Dunlop and Fitton [3]. The oldest rocks on the island are basal hyaloclastite breccias, which contain fragments of fresh tholeiite, dated at $31 \mathrm{Ma}$. On top of this basal unit are subhorizontal basaltic flows, intruded by tristanite and trachyphonolite plugs, and overlain by phonolite lavas. The basaltic flows can be divided into a lower series of alkali basalt and hawaiite overlain by a suite of nephelinite and basanite flows, which Fitton and Hughes [33] termed the older and the younger lava series, respectively.

The older lavas range in age from 24 (alkali basalt) to $19 \mathrm{Ma}$ (hawaiite), while the younger lavas range from 5.6 (nephelinite) to $3.5 \mathrm{Ma}$ (basanite). The plugs give ages ranging from 6.9 to 3.9 Ma. Dunlop and Fitton [3] reported a $\mathrm{Rb}-\mathrm{Sr}$ isochron of ca. $5.9 \mathrm{Ma}$, defined by the younger lava series and all the intrusive rocks, which suggests a cogenetic relationship between the intrusive rocks and the younger lava series. The isotopic compositions of $\mathrm{Sr}, \mathrm{Nd}$ and $\mathrm{Pb}$ for Principe are chiefly taken from Halliday et al. [2,32]. In addition, data for four hawaiites from the older lava series were analyzed as part of this study. We have also selected five samples from Halliday et al. [2], for which only isotopic ratios were measured, and analyzed their $\mathrm{Rb} / \mathrm{Sr}, \mathrm{Sm} /$ $\mathrm{Nd}$ and $\mathrm{U} / \mathrm{Pb}$ ratios through isotope dilution in order to better determine their initial isotopic compositions.

\subsection{São Tomé}

The oldest rocks on São Tomé are conglomerates, sandstones and shales of the Ubabudo Formation, which have a similar lithology to the Cretaceous sandstones in Gabon [34]. The volcanic successions are dominated by basic lavas, although evolved rocks are common and form part of a continuum from basalt to trachyte and phonolite with no compositional gap [20]. The chemical variations between these rocks can be explained by fractional crystallization of the observed phenocryst phases. Trachytes seem to be the oldest dated volcanic rocks on the island, with two $\mathrm{K}-\mathrm{Ar}$ ages of $15.7 \mathrm{Ma}$ [35] and 13 $\mathrm{Ma}$ [1], while all the other rocks are younger than $7.6 \mathrm{Ma}$ $[1,34]$. Lavas erupted in the last million years are entirely basaltic. The isotopic data for São Tomé were reported by Halliday et al. [2,32]. Only one sample, a ca. 13 Ma trachyte from São Tomé has been analyzed in this study to complement the existing data base.

\subsection{Pagalu}

Pagalu lies on the southwestern end of the volcanic chain. The petrology and geochemistry of the island have been reported by Cornen and Maury [36] and by Liotard et al. [37]. The oldest rocks on the island are hyaloclastite breccias that contain large clinopyroxene megacrysts and are intruded by numerous basaltic dikes. This basal unit is overlain by basaltic flows ranging in composition from basanite to $h y$-normative basalt. Numerous basanitic dikes intersect and feed the pile. The lava pile has also been intruded by tristanite and trachyte plugs. The evolved rocks in the island were probably produced by fractional crystallization of basanitic magmas, involving kaersutite, clinopyroxene and plagioclase [37].

Only one sample from Pagalu exists for which $\mathrm{Sr}, \mathrm{Nd}$ and $\mathrm{Pb}$ isotopic compositions have been reported [32]. This sample exhibits distinctly un- 
radiogenic $\mathrm{Pb}$ compared with other young oceanic sector Cameroon line basalts. In order to understand the origin of the Cameroon line magmas it is essential to obtain more comprehensive data for this island. The island is uninhabited and largely inaccessible at the present time. However, a suite of samples for a paleomagnetic study were collected by Piper and Richardson [38]. We have therefore used these samples in an attempt to complete our coverage of the Cameroon line.

All the Pagalu samples have a similar mineralogy but variable modal compositions; phenocrysts (mostly olivine and lesser amounts of pyroxene) make up roughly $20-45 \%$ of the total volume, and the matrix contains $10-20 \%$ of olivine plus pyroxene, $25-40 \%$ of plagioclase, and $5-15 \%$ of $\mathrm{Fe}-\mathrm{Ti}$ oxides. Some samples contain up to $10 \%$ of glass in their matrix. Phenocrysts are mostly euhedral to subhedral, varying from 0.5 to $4 \mathrm{~mm}$ in size, while the matrix grain size is generally less than $0.5 \mathrm{~mm}$. According to Piper and Richardson [38], these samples were collected from two series of lava flows. The early lava flows range in composition from basanite to $h y$-norm basalt (Table 1), while the more recent lava flows are entirely basanite. All samples have experienced variable degrees of secondary alteration. In particular, the phenocrysts and groundmass olivine have been partially serpentinized or replaced by red-brownish iddingsite. However, most of the pyroxenes in the matrix and the remaining minerals (e.g., plagioclase and $\mathrm{Fe}-\mathrm{Ti}$ oxides) are fresh. In general, the matrix contains most of the incompatible trace elements (e.g., $\mathrm{U}$, $\mathrm{Pb}, \mathrm{Rb}, \mathrm{Sr}$ ) and REEs that are of interest in this study, while olivines contain negligible amounts

Table 1

$\mathrm{Rb}-\mathrm{Sr}$ and $\mathrm{Sm}-\mathrm{Nd}$ isotopic data

\begin{tabular}{|c|c|c|c|c|c|c|c|c|c|c|c|c|c|}
\hline Sample & $\begin{array}{l}\text { Rock } \\
\text { Type }\end{array}$ & $\begin{array}{l}\text { Age } \\
\text { (Ma) }\end{array}$ & $\begin{array}{c}\mathrm{Rb} \\
\text { (ppm) }\end{array}$ & $\underset{(\mathrm{ppm})}{\mathrm{Sr}}{ }^{8}$ & $\begin{array}{c}{ }^{87} \mathrm{Rb} /{ }^{86} \mathrm{Sr} \\
\text { atomic }\end{array}$ & $\begin{array}{c}{ }^{87} \mathrm{Sr} /{ }^{86} \mathrm{Sr} \\
\pm 2 \sigma \text { errors }\end{array}$ & $\begin{array}{r}\left({ }^{(87} \mathrm{Sr} /{ }^{86} \mathrm{~S} r\right)_{\mathrm{t}} \\
\pm 2 \sigma \text { errors }\end{array}$ & $\begin{array}{c}\text { Sm } \\
(\mathrm{ppm})\end{array}$ & $\begin{array}{c}\mathrm{Nd} \\
(\mathrm{ppm})\end{array}$ & $\begin{array}{c}{ }^{147} \mathrm{Sm} / /^{144} \mathrm{Nd} \\
\text { atomic }\end{array}$ & $\begin{array}{l}{ }^{143} \mathrm{Nd} /{ }^{144} \mathrm{Nd} \\
\pm 2 \sigma \text { errors }\end{array}$ & $\begin{array}{c}\left({ }^{143} \mathrm{Nd} /{ }^{144} \mathrm{Nd}\right) \\
\pm 2 \sigma \text { errors }\end{array}$ & $\varepsilon(\mathrm{Nd})_{\mathrm{t}}$ \\
\hline \multicolumn{14}{|l|}{ Pagalu } \\
\hline AN3 & nb & 4.8 & 33.8 & 713 & 0.136 & $0.70334 \pm 1$ & $0.70333 \pm 1$ & 12.23 & 57.76 & 0.1280 & $0.512926 \pm 5$ & $0.512922 \pm 5$ & 5.7 \\
\hline AN4 & bn & 4.8 & 41.2 & 924 & 0.128 & $0.70364 \pm 1$ & $0.70363 \pm 1$ & 17.03 & 85.11 & 0.1210 & $0.512858 \pm 7$ & $0.512854 \pm 7$ & 4.3 \\
\hline AN7 & hb & 4.8 & 32.2 & 752 & 0.123 & $0.70374 \pm 1$ & $0.70373 \pm 1$ & 14.66 & 74.19 & 0.1195 & $0.512878 \pm 6$ & $0.512874 \pm 6$ & 4.7 \\
\hline AN8 & hb & 4.8 & 35.4 & 757 & 0.134 & $0.70353 \pm 1$ & $0.70352 \pm 1$ & 7.67 & 36.40 & 0.1274 & $0.512935 \pm 9$ & $0.512931 \pm 9$ & 5.8 \\
\hline AN10 & bn & 4.8 & 42.5 & 839 & 0.146 & $0.70325 \pm 2$ & $0.70324 \pm 2$ & 10.29 & 48.21 & 0.1290 & $0.512948 \pm 6$ & $0.512944 \pm 6$ & 6.1 \\
\hline AN11 & hb & 4.8 & 33.2 & 937 & 0.102 & $0.70338 \pm 1$ & $0.70337 \pm 1$ & 14.43 & 69.15 & 0.1262 & $0.512909+13$ & $0.512905 \pm 13$ & 5.3 \\
\hline ANTBM & $b n$ & $\leq 1$ & 41.2 & 815 & 0.145 & $0.70335 \pm 1$ & $0.70335 \pm 1$ & 17.11 & 81.68 & 0.1266 & $0.512929 \pm 9$ & $0.512929 \pm 9$ & 5.7 \\
\hline AN12 & bn & $\leq 1$ & 21.4 & 833 & 0.074 & $0.70334 \pm 1$ & $0.70334 \pm 1$ & 10.93 & 51.42 & 0.1285 & $0.512936 \pm 5$ & $0.512936 \pm 5$ & 5.8 \\
\hline AN13 & bn & $\leq 1$ & 41.7 & 834 & 0.144 & $0.70328 \pm 1$ & $0.70328 \pm 1$ & 13.87 & 65.09 & 0.1289 & $0.512972 \pm 6$ & $0.512972 \pm 6$ & 6.5 \\
\hline AN14 & bn & $\leq 1$ & 41.2 & 1035 & 0.115 & $0.70343 \pm 1$ & $0.70343 \pm 1$ & 13.73 & 67.14 & 0.1236 & $0.512930 \pm 7$ & $0.512930 \pm 7$ & 5.7 \\
\hline AN17 & bn & $\leq 1$ & 36.7 & 963 & 0.110 & $0.70340 \pm 1$ & $0.70340 \pm 1$ & 14.66 & 70.42 & 0.1259 & $0.512922 \pm 9$ & $0.512922 \pm 9$ & 5.5 \\
\hline AN18 & bn & $\leq 1$ & 48.7 & 931 & 0.150 & $0.70336 \pm 1$ & $0.70336 \pm 1$ & 7.21 & 33.76 & 0.1292 & $0.512931 \pm 7$ & $0.512931 \pm 7$ & 5.7 \\
\hline AN19 & bn & $\leq 1$ & 47.6 & 944 & 0.145 & $0.70337 \pm 2$ & $0.70337 \pm 2$ & 14.14 & 68.69 & 0.1244 & $0.512913 \pm 6$ & $0.512913 \pm 6$ & 5.4 \\
\hline AN20 & bn & $\leq 1$ & 29.5 & 855 & 0.099 & $0.70340 \pm 1$ & $0.70340 \pm 1$ & 15.58 & 74.30 & 0.1268 & $0.512922 \pm 8$ & $0.512922 \pm 8$ & 5.5 \\
\hline \multicolumn{14}{|l|}{ Principe } \\
\hline P6 & hw & 19 & 16.5 & 940 & 0.0535 & $0.70317 \pm 1$ & $0.70317 \pm 1$ & 11.20 & 55.68 & 0.1217 & $0.512902 \pm 9$ & $0.512853 \pm 7$ & 4.7 \\
\hline $\mathrm{P} 21$ & $h w$ & 19 & 19.8 & 609 & 0.0935 & $0.70315 \pm 1$ & $0.70311 \pm 1$ & 7.89 & 36.08 & 0.1322 & $0.512900 \pm 9$ & $0.512853 \pm 7$ & 4.7 \\
\hline P25 & hw & 19 & 27.7 & 898 & 0.121 & $0.70311 \pm 1$ & $0.70297 \pm 1$ & 11.36 & 53.42 & 0.1286 & $0.512893 \pm 8$ & $0.512849 \pm 8$ & 4.6 \\
\hline P26 & $h w$ & 19 & 26.5 & 917 & 0.0831 & $0.70311 \pm 2$ & $0.70312 \pm 1$ & 10.70 & 50.19 & 0.1290 & $0.512895 \pm 11$ & $0.512868 \pm 7$ & 5.0 \\
\hline $\mathrm{P} 12^{*}$ & tr & 6 & 165 & 1097 & 0.434 & $0.70322 \pm 1$ & $0.70318 \pm 1$ & 5.70 & 35.29 & 0.09764 & $0.512922 \pm 10$ & $0.512918 \pm 10$ & 5.6 \\
\hline P13* & tr & 6 & 174 & 1183 & 0.424 & $0.70301 \pm 2$ & $0.70297 \pm 2$ & 6.227 & 39.36 & 0.09564 & $0.512865 \pm 20$ & $0.512861 \pm 20$ & 4.5 \\
\hline P39* & ph & 6 & 262 & 77.5 & 9.74 & $0.70378 \pm 2$ & $0.70294 \pm 2$ & 1.603 & 12.99 & 0.07463 & $0.512940 \pm 8$ & $0.512937 \pm 8$ & 5.9 \\
\hline $\mathrm{P} 40^{*}$ & ph & 6 & 209 & 235 & 2.56 & $0.70328 \pm 1$ & $0.70306 \pm 1$ & 2.598 & 20.34 & 0.07722 & $0.512906 \pm 8$ & $0.512903 \pm 8$ & 5.3 \\
\hline $\mathrm{P} 41^{*}$ & $\mathrm{tp}$ & 6 & 169 & 485 & 1.01 & $0.70300 \pm 1$ & $0.70291 \pm 1$ & 3.675 & 25.77 & 0.08623 & $0.512930 \pm 7$ & $0.512927 \pm 7$ & 5.8 \\
\hline \multicolumn{14}{|l|}{ São Tomé } \\
\hline ST57 & ty & 13 & 120 & 223 & 1.54 & $0.70388 \pm 1$ & $0.70360 \pm 3$ & 10.55 & 71.73 & 0.08894 & $0.512875 \pm 5$ & $0.512867 \pm 8$ & 5.0 \\
\hline
\end{tabular}

All $\mathrm{Sr}$ isotopic analyses were normalized to ${ }^{86} \mathrm{Sr} /{ }^{88} \mathrm{Sr}=0.1194$ and $\mathrm{Nd}$ analyses were normalized to ${ }^{146} \mathrm{Nd} /{ }^{144} \mathrm{Nd}=0.7219$. $\lambda^{87} \mathrm{Rb}=1.42 \pm 10^{-11} \mathrm{y}^{-1} ; \lambda^{147} \mathrm{Sm}=6.54 \pm 10^{-12} \mathrm{y}^{-1} ;{ }^{143} \mathrm{Nd} /{ }^{144} \mathrm{Nd}$ CHUR $=0.512638$ and ${ }^{147} \mathrm{Sm} /{ }^{144} \mathrm{Nd} \mathrm{CHUR}=0.1966 . \mathrm{nb}=n e-$ norm basalt, $\mathrm{hb}=h y$-norm basalt, $\mathrm{bn}=$ basanite, $\mathrm{hw}=$ hawaiite, $\mathrm{tr}=$ tristanite, $\mathrm{tp}=$ trachyphonolite, $\mathrm{ph}=$ phonolite, ty $=$ trachyte.

* Isotopic compositions were taken from [2]. 
of these trace elements. This implies that even with the secondary alteration, the samples still retain information about the isotopic and trace element characteristics of their mantle sources. The $\mathrm{Ba} / \mathrm{Rb}$ ratio is particularly sensitive to alteration [39]. The $\mathrm{Rb} / \mathrm{U}, \mathrm{Ba} / \mathrm{Rb}$ and $\mathrm{Rb} / \mathrm{Sr}$ ratios are plotted against the percentage of grains (Fig. 2) and display some degree of alteration. In general, $\mathrm{Rb}$ may easily be leached out during alteration, while $\mathrm{Ba}$ and $\mathrm{Sr}$ are relatively immobile. The lack of any correlation in Fig. 2 and consistency with data for OIB elsewhere [39] suggests that the trace element compositions in these samples are probably valid, although they should be treated with caution and are not interpreted in detail in this study.

Several basalts from Pagalu were dated by ${ }^{40} \mathrm{Ar} /{ }^{39} \mathrm{Ar}$ step heating and the results are shown in Fig. 3. The data define two series of integrated ages, $4.8 \pm 0.2 \mathrm{Ma}$ and $\leqslant 1 \mathrm{Ma}$, corresponding to the two series recognized by Piper and Richardson [38]. The calculated plateau ages for three older samples vary from 4.7 to $4.8 \mathrm{Ma}$ (Fig. 3a), consistent with the integrated ages. In addition, the ages calculated from the least-square fits of these samples on correlation diagrams of ${ }^{36} \mathrm{Ar} /$ ${ }^{40} \mathrm{Ar}$ and ${ }^{39} \mathrm{Ar} /{ }^{40} \mathrm{Ar}$ also fall in a similar range between 4.7 and $4.8 \mathrm{Ma}$. The agreement of the age, $4.8 \pm 0.2 \mathrm{Ma}$, from different calculations, plateau ages, regression plots and total gas ages, suggests that the integrated age is the eruption age of the older lavas. The integrated ages for three younger samples vary from 0.2 to $1 \mathrm{Ma}$ (Fig. $3 b$ ), with only one sample showing a plateau age of $0.4 \pm 0.1 \mathrm{Ma}$. Nonetheless, they clearly represent a separate and relatively recent $(<1 \mathrm{Ma})$ volcanic event on the island. Piper and Richardson [38] reported two $\mathrm{K}-\mathrm{Ar}$ ages, 18.4 and 2.6 $\mathrm{Ma}$, for older and younger lava flows. Although the results from this study confirm the existence of two series of lava flows, the ages are much younger than those obtained by Piper and Richardson [38], despite the use of the same sample suite. Cornen and Maury [36] dated one of the many basanitic dikes, which intersected (and fed) the presumably older lava flows, and obtained a $\mathrm{K}-\mathrm{Ar}$ age of $5.35 \pm 0.25 \mathrm{Ma}$. This age is similar to that obtained for the older lavas in

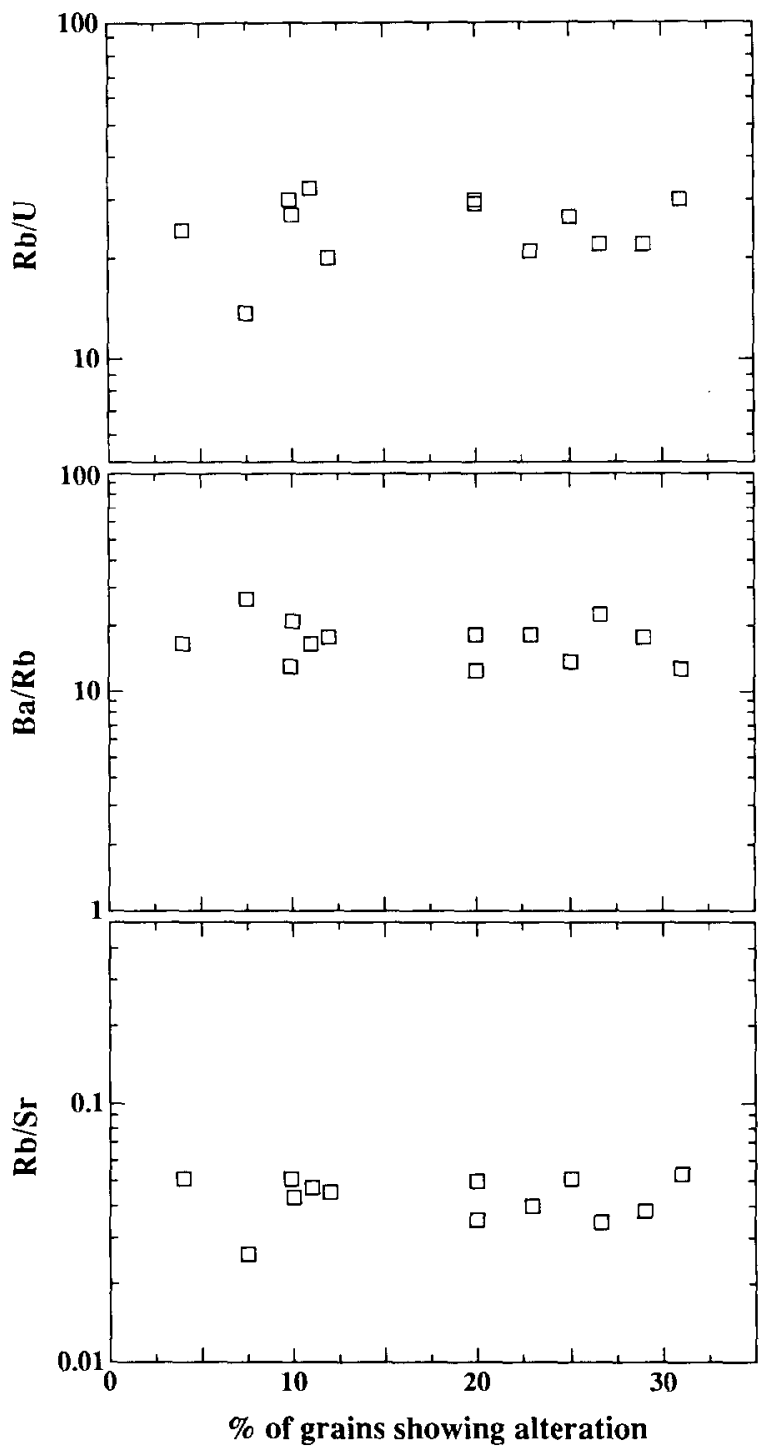

Fig. 2. Plot of $\mathrm{Rb} / \mathrm{U}, \mathrm{Ba} / \mathrm{Rb}$ and $\mathrm{Rb} / \mathrm{Sr}$ ratios of the Pagalu samples versus the percentage of the grains showing alteration within each sample. The percentage of grains showing alteration was obtained through integration over an area of 0.5 $\mathrm{cm}^{2}$ in thin section.

this study, suggesting the older lavas and the dikes were coeval.

The most important feature of the new ages is that the earliest volcanism from each island decreases oceanward. Pollitz [40] has suggested that the African plate rotated counter-clockwise about a pole position near the Azores over the past 30 
myr, implying that the absolute motion of the African plate did not coincide with the transform faults of the local Atlantic oceanic crust. Similar conclusions have been drawn from the study of space and time distributions of the volcanism in the South Atlantic [41]. Reconstructing African plate motion using the proposed rotation speeds and direction [40] leads to the conclusion that the first volcanic activity of each of the Cameroon line volcanic islands (31 Ma for Principe; $\geqslant 13$ Ma for São Tomé; and 4.8 Ma for Pagalu) initiated from roughly the same sublithospheric location. This implies that the source region of the Cameroon line oceanic sector has been decoupled from the motion of the African plate and is located in the deep mantle. This is the first time such a feature has been documented for this volcanic chain, and is inconsistent with previous models for the origin of the Cameroon line.

\section{Isotopic and chemical compositions}

\subsection{Isotopic compositions of young volcanic rocks}

Initial $\mathrm{Sr}$ and $\mathrm{Nd}$ isotopic ratios of young basaltic rocks $(<10 \mathrm{Ma})$ for Principe, São Tomé and Pagalu are presented in Table 1. They are plotted along with fields for Atlantic MORB, Ascension, Madeira, Cameroon line continent/ ocean boundary (c.o.b.) and two HIMU-type ocean islands, St. Helena and Mangaia, in Fig. 4. In general, Principe, São Tomé and Pagalu have a similar range of $\mathrm{Nd}$ isotopic compositions but distinct $\mathrm{Sr}$ isotopic ratios. There is an increase in $\left({ }^{87} \mathrm{Sr} /{ }^{86} \mathrm{Sr}\right)_{t}$ with distance from the c.o.b. Principe has relatively a unradiogenic $\mathrm{Sr}$ isotopic composition, overlapping with São Tomé, and the data for both islands plot towards HIMU mantle [7]. Pagalu has the most radiogenic $\mathrm{Sr}$ and does not
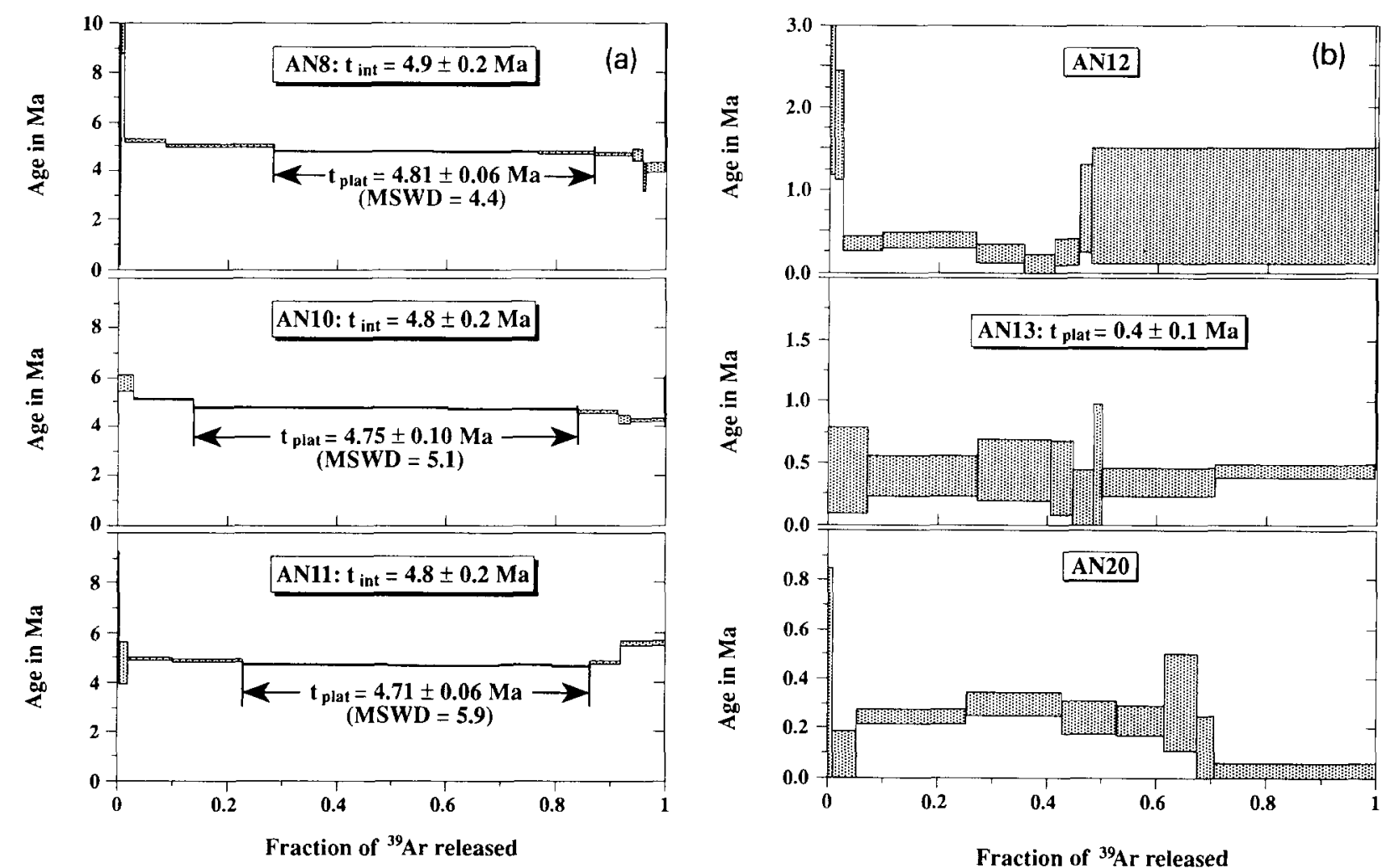

Fig. 3. ${ }^{40} \mathrm{Ar}-{ }^{39} \mathrm{Ar}$ age spectrum for Pagalu basalts. The uncertainty shown for each step is $2 \sigma$. $\mathbf{t}_{\text {int }}=$ integrated total gas age; $t_{\text {plat }}=$ calculated plateau age. Three samples each from (a) the older and (b) the younger lava flows [38] are plotted. 
overlap with either island. The observed variations in $\mathrm{Sr}$ isotopic composition among these three islands reflect either isotopic heterogeneity in the source mantle or mixing of different mantle end members. In contrast to the oceanic sector, the c.o.b. shows relatively unradiogenic $\mathrm{Nd}$ and radiogenic Sr. This suggests that the volcanic islands from the oceanic sector may be tapping sources that are not related to the c.o.b. volcanic centers, or that other components, for example, subcontinental lithosphere, are involved in the genesis of c.o.b. lavas.

The geographic control on $\mathrm{Sr}$ isotopic composition finds some parallels in $\mathrm{Pb}$ isotopic composition (Table 2). Pagalu has the most unradiogenic initial $\mathrm{Pb}$ isotopic compositions and plots distinctly away from the other two volcanic islands (Fig. 4), slightly overlapping with Atlantic MORB. Principe and São Tomé both have similar and more radiogenic $\mathrm{Pb}$ isotopic compositions relative

Table 2

$\mathrm{U}-\mathrm{Pb}$ isotopic data

\begin{tabular}{|c|c|c|c|c|c|c|c|c|c|c|c|}
\hline Sample & $\begin{array}{l}\text { Rock } \\
\text { Type }\end{array}$ & $\begin{array}{l}\text { Age } \\
(\mathrm{Ma})\end{array}$ & $\begin{array}{c}\mathrm{U} \\
(\mathrm{ppm})\end{array}$ & $\begin{array}{c}\mathrm{Pb} \\
(\mathrm{ppm})\end{array}$ & $\begin{array}{l}{ }^{238} \mathrm{U} /{ }^{204} \mathrm{~Pb} \\
\text { atomic }\end{array}$ & ${ }^{206} \mathrm{~Pb} / 204 \mathrm{~Pb}$ & ${ }^{201} \mathrm{~Pb} /{ }^{204} \mathrm{~Pb}$ & ${ }^{208} \mathrm{~Pb} / 204 \mathrm{~Pb}$ & $\left({ }^{206} \mathrm{~Pb} /{ }^{204} \mathrm{~Pb}\right)_{\mathrm{t}}$ & $\left({ }^{207} \mathrm{~Pb} /{ }^{204} \mathrm{~Pb}\right)_{\mathrm{t}}$ & $\left({ }^{208} \mathrm{~Pb} / 204 \mathrm{~Pb}\right)_{\mathrm{t}}$ \\
\hline \multicolumn{12}{|l|}{ Pagalu } \\
\hline AN3 & nb & 4.8 & 1.16 & 2.86 & 26.0 & 18.955 & 15.598 & 38.80 & 18.935 & 15.597 & 38.78 \\
\hline AN4 & bn & 4.8 & 2.07 & 4.41 & 30.2 & 18.980 & 15.585 & 38.92 & 18.957 & 15.584 & 38.89 \\
\hline AN7 & $\mathrm{hb}$ & 4.8 & 1.21 & 3.53 & 22.1 & 19.095 & 15.595 & 39.09 & 19.079 & 15.594 & 39.07 \\
\hline AN7(d) & & & & & & 19.070 & 15.591 & 39.12 & 19.054 & 15.590 & 39.10 \\
\hline AN8 & hb & 4.8 & 1.09 & 3.32 & 21.4 & 19.272 & 15.640 & 39.26 & 19.257 & 15.639 & 39.24 \\
\hline AN8(d) & & & & & & 19.235 & 15.647 & 39.27 & 19.219 & 15.646 & 39.25 \\
\hline AN10 & bn & 4.8 & 1.41 & 3.45 & 26.1 & 18.866 & 15.608 & 38.69 & 18.846 & 15.607 & 38.67 \\
\hline AN11 & hb & 4.8 & 1.15 & 2.92 & 25.6 & 19.217 & 15.644 & 39.18 & 19.198 & 15.643 & 39.16 \\
\hline AN7BM & bn & $<1$ & 1.71 & 4.93 & 22.3 & 18.901 & 15.611 & 38.84 & 18.901 & 15.611 & 38.84 \\
\hline AN12 & bn & $<1$ & 1.57 & 3.35 & 30.2 & 18.983 & 15.610 & 38.87 & 18.983 & 15.610 & 38.87 \\
\hline AN12(d) & & & & & & 18.981 & 15.608 & 38.89 & 18.981 & 15.608 & 38.89 \\
\hline $\mathrm{AN} 13$ & bn & $<1$ & 1.40 & 2.64 & 34.3 & 19.049 & 15.580 & 38.80 & 19.049 & 15.580 & 38.80 \\
\hline AN13(d) & & & & & & 19.039 & 15.592 & 38.84 & 19.039 & 15.592 & 38.84 \\
\hline AN14 & $b n$ & $<1$ & 1.98 & 4.70 & 27.1 & 18.941 & 15.626 & 38.99 & 18.941 & 15.626 & 38.99 \\
\hline AN17 & bn & $<1$ & 1.67 & 3.74 & 28.7 & 18.971 & 15.616 & 38.95 & 18.971 & 15.616 & 38.95 \\
\hline AN17(d) & & & & & & 18.965 & 15.619 & 38.96 & 18.965 & 15.619 & 38.96 \\
\hline AN18 & bn & $<1$ & 1.62 & 3.72 & 28.0 & 18.895 & 15.618 & 38.89 & 18.895 & 15.618 & 38.89 \\
\hline AN18(d) & & & & & & 18.889 & 15.618 & 38.89 & 18.889 & 15.618 & 38.89 \\
\hline AN19 & $b n$ & $<1$ & 1.80 & 3.64 & 31.9 & 18.890 & 15.629 & 38.93 & 18.890 & 15.629 & 38.93 \\
\hline AN20 & bn & $<1$ & 1.34 & 3.72 & 23.1 & 18.909 & 15.629 & 38.96 & 18.909 & 15.629 & 38.96 \\
\hline \multicolumn{12}{|l|}{ Principe } \\
\hline P6 & hw & 19 & 0.991 & 2.64 & 24.8 & 19.859 & 15.676 & 39.73 & 19.786 & 15.672 & 39.63 \\
\hline P21 & hw & 19 & 0.884 & 1.70 & 34.3 & 19.836 & 15.673 & 39.71 & 19.734 & 15.668 & 39.58 \\
\hline P25 & hw & 19 & 1.00 & 2.14 & 30.8 & 19.637 & 15.675 & 39.51 & 19.547 & 15.670 & 39.39 \\
\hline P26 & hw & 19 & 1.23 & 2.33 & 34.6 & 19.760 & 15.662 & 39.57 & 19.658 & 15.657 & 39.44 \\
\hline P12* & tr & 6 & 4.57 & 13.1 & 23.2 & 20.226 & 15.680 & 39.86 & 20.208 & 15.679 & 39.84 \\
\hline P13* & tr & 6 & 4.94 & 13.9 & 23.6 & 20.237 & 15.701 & 39.93 & 20.219 & 15.700 & 39.91 \\
\hline P39* & $\mathrm{ph}$ & 6 & 16.2 & 21.9 & 49.0 & 20.259 & 15.677 & 39.80 & 20.217 & 15.675 & 39.75 \\
\hline $\mathrm{P} 40^{*}$ & $\mathrm{ph}$ & 6 & 6.71 & 9.07 & 49.1 & 20.285 & 15.673 & 39.82 & 20.243 & 15.671 & 39.77 \\
\hline $\mathrm{P}_{4} 1^{*}$ & tp & 6 & 7.77 & 13.0 & 39.6 & 20.190 & 15.684 & 39.82 & 20.156 & 15.682 & 39.78 \\
\hline \multicolumn{12}{|l|}{ São Tomé } \\
\hline ST57 & ty & 13 & 1.92 & 4.90 & 25.6 & 19.433 & 15.655 & 39.55 & 19.381 & 15.652 & 39.49 \\
\hline
\end{tabular}

All $\mathrm{Pb}$ measurements have been corrected for fractionation and discrimination with a factor of $0.1 \%$ per a.m.u., based on measurements of NBS 981 standard.The $2 \sigma$ uncertainties for the isotopic composition measurements are roughly or better than $0.1 \%$. Some duplicate, with (d), analyses are listed for comparison.nb $=n e$-norm basalt, $h b=h y$-norm basalt, bn $=$ basanite hw $=$ hawaiite, $\operatorname{tr}=$ tristanite, $\mathrm{tp}=$ trachyphonolite, $\mathrm{ph}=$ phonolite, $t y=$ trachyte. ${ }^{*}$ Isotopic composition data were taken from [2]. 
to those of Pagalu, with a few Principe samples showing higher ${ }^{206} \mathrm{~Pb} /{ }^{204} \mathrm{~Pb}$ than São Tomé. The $\left({ }^{207} \mathrm{~Pb} /{ }^{204} \mathrm{~Pb}\right)_{\mathrm{t}}$ of São Tomé, Principe and the c.o.b. are similar, although the c.o.b. has the highest $\left({ }^{206} \mathrm{~Pb} /{ }^{204} \mathrm{~Pb}\right)_{\mathrm{t}}$ and $\left({ }^{208} \mathrm{~Pb} /{ }^{204} \mathrm{~Pb}\right)_{\mathrm{t}}$.

Even though the distances from São Tomé to either Pagalu or Principe are roughly similar, there are only subtle differences between Principe and São Tomé in $\mathrm{Sr}$ and $\mathrm{Pb}$ isotopic ratios, but there are major differences between Pagalu and the other two islands, especially in $\mathrm{Pb}$. Another important feature is that while the ${ }^{206} \mathrm{~Pb} /{ }^{204} \mathrm{~Pb}$ and ${ }^{208} \mathrm{~Pb} /{ }^{204} \mathrm{~Pb}$ increase toward the c.o.b. [2], $\mathrm{Sr}$ isotopic compositions of lavas from the c.o.b. are no more radiogenic than those of Pagalu.

\subsection{Temporal variations in isotopic compositions}

The changes in initial $\mathrm{Sr}, \mathrm{Nd}$ and $\mathrm{Pb}$ isotopic compositions with eruption age for Principe, São
Tomé and Pagalu are illustrated in Fig. 5. Pagalu samples do not display any systematic differences in isotopic composition between the lava flows of the two age groups.

The oldest samples from Principe and São Tomé plot close to the field defined by the Pagalu samples in Fig. 5. In each case the $31 \mathrm{Ma}$ old sample from Principe deviates from the rest of the Principe samples and plots within the field of Pagalu. Similarly, the 13 Ma trachyte from São Tomé deviates from the younger samples and plots toward the field of Pagalu. There is little doubt that the earliest Principe and São Tomé magmas originated from a mantle source similar to that of the Pagalu magmas. The youngest samples for both Principe and São Tomé have the most radiogenic $\mathrm{Pb}$ (Fig. 5). The difference in $\mathrm{Pb}$ isotopic ratios among each group of samples cannot be reconciled by the time-integrated effect of
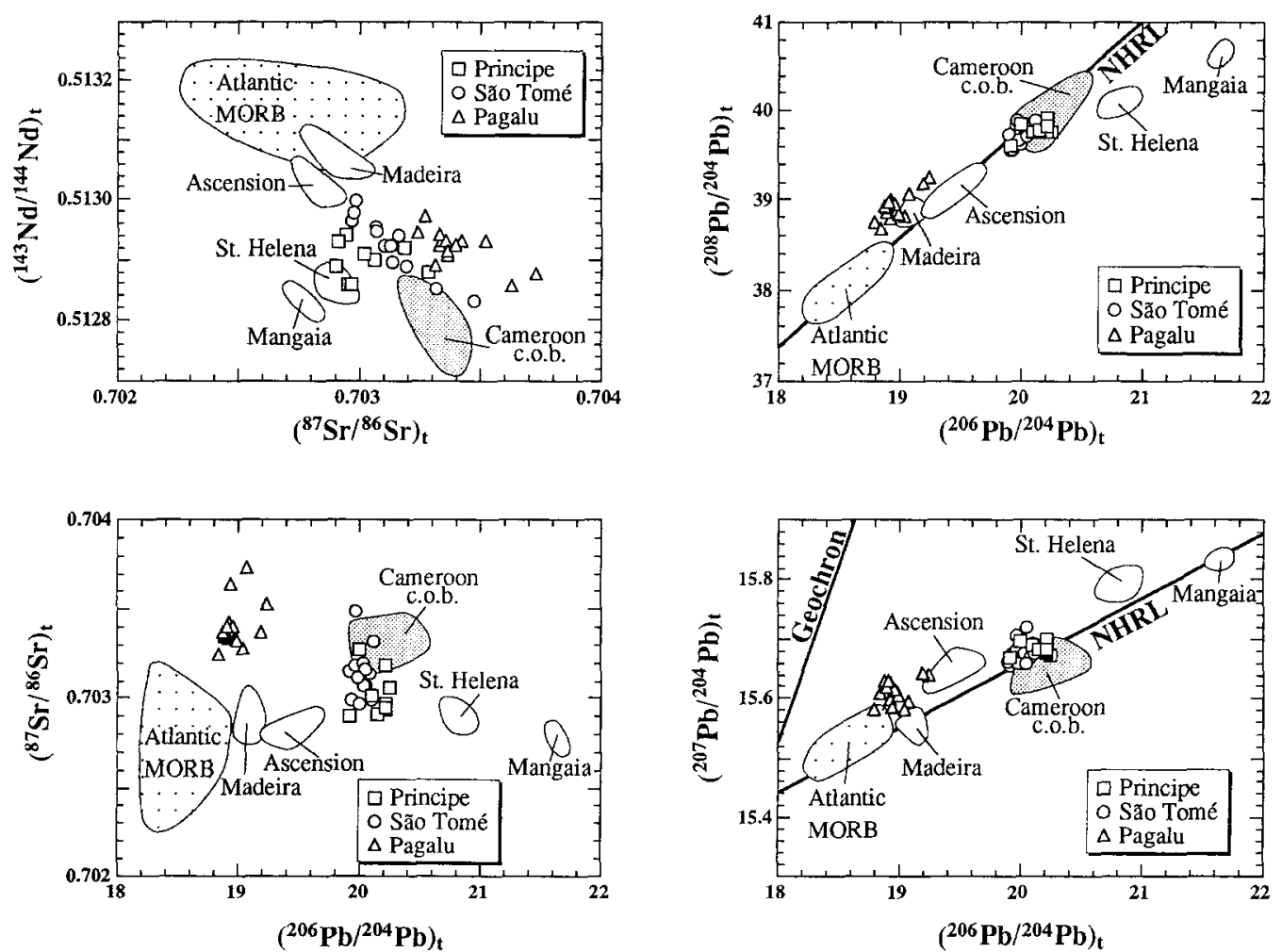

Fig. 4. Plots of initial $\mathrm{Sr}$ versus $\mathrm{Nd}$ and $\mathrm{Pb}$ for the young ( $<10 \mathrm{Ma}$ ) samples from Principe, São Tomé and Pagalu, along with the data of the Atlantic MORB [53], Madeira and Ascension [31], Cameroon line c.o.b. [2,32] and two HIMU-type ocean islands, St. Helena [54] and Mangaia [43]. 
radioactive decay, given the range in ${ }^{207} \mathrm{~Pb} /{ }^{204} \mathrm{~Pb}$ and small measured $\mu\left({ }^{238} \mathrm{U} /{ }^{204} \mathrm{~Pb}\right)$ values (Table 2), which should be a maximum for their sources.

\subsection{Major and trace elements}

Both Principe and São Tomé display considerable variation in $\mathrm{SiO}_{2}$ and $\mathrm{MgO}$ (Table 3), but reveal no systematic relationship with isotopic compositions (Fig. 6). However, samples from Pagalu show slight negative and positive correlation between $\mathrm{MgO}$ and $\mathrm{Sr}$ and $\mathrm{Nd}$ isotopic ratios, respectively. The implication is that some magmas incorporated $\mathrm{Sr}$ and $\mathrm{Nd}$ in the lithosphere, through assimilation of a slightly enriched source, while undergoing differentiation (AFC), as reported for the Canary Islands [17,18]. However, the effect, even in Pagalu, is small and does not affect the conclusions regarding the fundamental magma sources.

Despite the large differences in $\mathrm{Sr}$ and $\mathrm{Pb}$ isotopic ratio, the $<10 \mathrm{Ma}$ basaltic lavas from these three islands have similar primitive mantle-normalized trace element patterns. This is illustrated in Fig. 7, where the average compositions of all $<10 \mathrm{Ma}$ samples with $\geqslant 4 \% \mathrm{MgO}$ are plotted from the data in Tables 1-3 and $[1,20]$. In general, the patterns display enrichment in highly incompatible elements, such as $\mathrm{Ba}$ and $\mathrm{Nb}$, and the degree of enrichment decreases for less incompatible elements, such as $\mathrm{Sm}$ and $\mathrm{Y}$, as is typical for small degrees of partial melting. The lavas also have distinct negative $\mathrm{K}$ anomalies. Similar patterns have been found throughout the entire volcanic chain [1]. The similar trace element compositions in $<10 \mathrm{Ma}$ basalts, but very different $\mathrm{Sr}$ and $\mathrm{Pb}$ isotopic ratios, between $\mathrm{Pa}$ -

Table 3

Whole rock XRF data for Pagalu basalts

\begin{tabular}{|c|c|c|c|c|c|c|c|c|c|c|c|c|c|c|}
\hline Sample & AN3 & AN4 & AN7 & AN7BM & AN8 & AN10 & AN11 & AN12 & AN13 & AN14 & AN17 & AN18 & AN19 & AN20 \\
\hline \multicolumn{15}{|c|}{ Major elements (wt\%) } \\
\hline $\mathrm{SiO}_{2}$ & 45.99 & 44.51 & 47.38 & 43.12 & 47.65 & 42.38 & 45.92 & 43.41 & 42.21 & 41.79 & 43.16 & 43.00 & 43.41 & 43.57 \\
\hline $\mathrm{TiO}_{2}$ & 3.44 & 3.97 & 3.61 & 3.26 & 3.84 & 3.12 & 3.81 & 3.07 & 3.08 & 2.95 & 3.06 & 3.06 & 2.74 & 2.94 \\
\hline $\mathrm{Al}_{2} \mathrm{O}_{3}$ & 12.55 & 12.48 & 13.95 & 12.36 & 15.41 & 10.80 & 13.20 & 11.36 & 10.62 & 12.61 & 12.49 & 12.46 & 12.29 & 12.41 \\
\hline $\mathrm{FeO}$ & 13.09 & 13.72 & 12.79 & 14.31 & 12.71 & 13.84 & 12.82 & 14.15 & 13.81 & 14.46 & 14.34 & 14.46 & 13.78 & 14.08 \\
\hline $\mathrm{MgO}$ & 8.48 & 8.16 & 6.38 & 10.62 & 4.55 & 14.50 & 8.08 & 12.85 & 14.81 & 10.47 & 9.26 & 9.39 & 10.82 & 10.63 \\
\hline $\mathrm{CaO}$ & 10.58 & 10.94 & 9.46 & 9.99 & 9.06 & 9.95 & 9.96 & 10.08 & 9.98 & 11.00 & 10.98 & 11.17 & 10.53 & 10.66 \\
\hline $\mathrm{Na}_{2} \mathrm{O}$ & 2.57 & 2.79 & 2.49 & 3.00 & 3.21 & 3.08 & 2.57 & 2.10 & 3.08 & 2.70 & 2.76 & 2.91 & 3.00 & 2.75 \\
\hline $\mathrm{K}_{2} \mathrm{O}$ & 1.54 & 1.19 & 1.77 & 1.73 & 1.85 & 0.65 & 1.77 & 1.30 & 0.64 & 0.67 & 0.96 & 0.63 & 1.17 & 1.30 \\
\hline $\mathrm{MnO}$ & 0.17 & 0.18 & 0.14 & 0.18 & 0.15 & 0.19 & 0.17 & 0.18 & 0.19 & 0.21 & 0.20 & 0.20 & 0.20 & 0.23 \\
\hline $\mathrm{P}_{2} \mathrm{O}_{5}$ & 0.64 & 0.90 & 0.75 & 0.82 & 0.80 & 0.87 & 0.85 & 0.90 & 0.85 & 1.47 & 1.10 & 1.05 & 0.95 & 1.01 \\
\hline Total & 99.05 & 98.84 & 98.71 & 99.38 & 99.22 & 99.38 & 99.13 & 99.40 & 99.25 & 98.32 & 98.31 & 98.33 & 98.89 & 99.59 \\
\hline \multicolumn{15}{|c|}{ Trace elements (ppm) } \\
\hline $\mathrm{V}$ & 302 & 311 & 316 & 274 & 321 & 272 & 300 & 265 & 266 & 279 & 300 & 307 & 251 & 275 \\
\hline $\mathrm{Ba}$ & 526 & 725 & 675 & 669 & 579 & 544 & 606 & 571 & 516 & 743 & 648 & 618 & 640 & 665 \\
\hline $\mathrm{Sc}$ & 24 & 27 & 26 & 26 & 21 & 26 & 24 & 26 & 25 & 29 & 28 & 29 & 29 & 25 \\
\hline $\mathrm{La}$ & 41 & 61 & 51 & 50 & 51 & 50 & 47 & 50 & 47 & 75 & 61 & 62 & 67 & 58 \\
\hline $\mathrm{Ce}$ & 87 & 136 & 119 & 106 & 120 & 101 & 109 & 107 & 100 & 152 & 125 & 122 & 136 & 119 \\
\hline $\mathrm{Cr}$ & 561 & 396 & 338 & 246 & 137 & 710 & 335 & 514 & 541 & 299 & 376 & 379 & 345 & 348 \\
\hline $\mathrm{Ni}$ & 256 & 229 & 180 & 204 & 104 & 505 & 225 & 406 & 506 & 252 & 267 & 252 & 245 & 269 \\
\hline $\mathrm{Cu}$ & 65 & 52 & 44 & 48 & 41 & 46 & 60 & 38 & 41 & 37 & 56 & 52 & 49 & 60 \\
\hline $\mathrm{Zn}$ & 110 & 123 & 114 & 142 & 110 & 126 & 118 & 142 & 123 & 163 & 136 & 137 & 142 & 134 \\
\hline Th & 4 & 6 & 5 & 7 & 5 & 6 & 4 & 6 & 5 & 9 & 7 & 7 & 9 & 7 \\
\hline$Y$ & 29 & 34 & 32 & 33 & 36 & 32 & 32 & 32 & 31 & 41 & 35 & 36 & 37 & 35 \\
\hline$Z r$ & 291 & 474 & 405 & 339 & 404 & 278 & 365 & 305 & 275 & 352 & 322 & 311 & 312 & 313 \\
\hline $\mathrm{Nb}$ & 52 & 63 & 53 & 71 & 54 & 62 & 52 & 65 & 61 & 77 & 68 & 65 & 67 & 68 \\
\hline
\end{tabular}

Total $\mathrm{Fe}$ as $\mathrm{FeO}$. The concentrations of $\mathrm{Rb}, \mathrm{Sr}, \mathrm{Sm}, \mathrm{Nd}, \mathrm{U}$ and $\mathrm{Pb}$ are shown in Table 1 and 2. 
galu and Principe suggest that the source region components should have roughly the same trace element compositions. In addition, the degrees, and hence integrated depths, of partial melting should be approximately the same for these three islands.

Sun and McDonough [42] suggested that the $\mathrm{Ba} / \mathrm{Nb}$ and $\mathrm{La} / \mathrm{Nb}$ ratios of OIB are correlated with the HIMU type (low ${ }^{87} \mathrm{Sr} /{ }^{86} \mathrm{Sr}$ ), having low $\mathrm{Ba} / \mathrm{Nb}$, and $\mathrm{EM}$ type (high ${ }^{87} \mathrm{Sr} /{ }^{86} \mathrm{Sr}$ ), having high $\mathrm{Ba} / \mathrm{Nb}$. Pagalu has the highest $\mathrm{Ba} / \mathrm{Nb}$ and ${ }^{87} \mathrm{Sr} /{ }^{86} \mathrm{Sr}$ ratios, even though the difference is small (Fig. 8). The low $\mathrm{Ba} / \mathrm{Nb}$ and $\mathrm{Sr}$ isotopic ratios in Principe and São Tomé are consistent with the isotopic evidence for the influence of a HIMU component in the mantle source for these two islands. This is supported by a negative correlation between the $\mathrm{Ba} / \mathrm{Nb}$ and ${ }^{206} \mathrm{~Pb} /{ }^{204} \mathrm{~Pb}$ ratios among these three islands and some HIMU type OIBs (Fig. 8). The HIMU type OIBs have the most radiogenic ${ }^{206} \mathrm{~Pb} /{ }^{204} \mathrm{~Pb}$ and the lowest $\mathrm{Ba} / \mathrm{Nb}$ ratios [42-45], while Pagalu has the exact opposite. Principe and São Tomé plot in between HIMU type OIBs and the island of Pagalu, and the trace elements and isotopic compositions of these two islands can be generated through admixing HIMU component to the 'Pagalu source'.

\section{Discussion}

All three volcanic islands in this study have a substantial history of volcanic activity. Principe has had the longest eruption history (ca. 30 myr). Given the small size of the island (roughly $15 \times 20$ $\mathrm{km}$ ), the magma conduits supplying Principe must have been capable of rejuvenation, despite long periods of apparent quiescence and the tapping of distinct heterogeneities in the mantle, since the movement of the African plate has locally
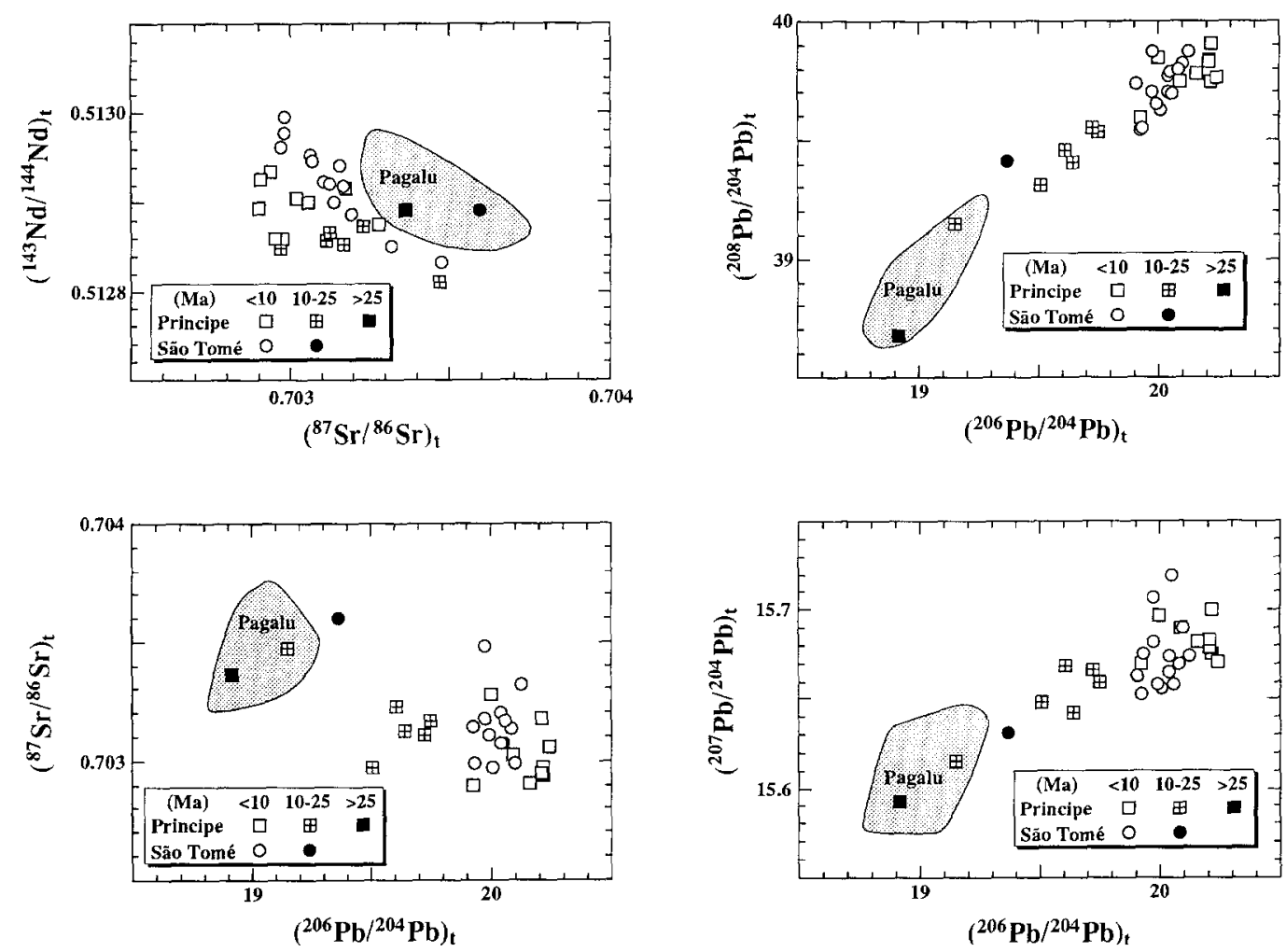

Fig. 5. Plots of initial $\mathrm{Sr}$ versus Nd and $\mathrm{Pb}$ for samples from Principe, São Tomé and Pagalu. The samples from Principe and São Tomé are divided into $<10 \mathrm{Ma}, 10-25 \mathrm{Ma}$ and $>25 \mathrm{Ma}$, while the samples from Pagalu are shown with the shaded area. 
exceeded $500 \mathrm{~km}$ over the same period of time [40]. Similar arguments can be made for São Tomé.

The space-time variations in isotopic ratios observed in the oceanic sector of the Cameroon line indicate the gradual incorporation of HIMU components. The source from which the islands are initiated has slightly enriched isotopic compositions relative to that of the Atlantic MORB, as shown by the island of Pagalu. However, instead of displaying mixing trends towards a HIMU component, $<10 \mathrm{Ma}$ samples from each island show subparallel linear correlations in $\mathrm{Sr}-\mathrm{Nd}$ and $\mathrm{Pb}-\mathrm{Sr}$ isotopic diagrams that are explicable by mixing between a depleted MORB mantle (DMM) and an enriched mantle (EMI) component (Fig. 9). The implication is that, despite the general mixing scheme between HIMU and the

\begin{tabular}{lccc} 
(Ma) & $<10$ & $10-25$ & $>25$ \\
Principe & $\square$ & ⿴囗十 & \\
São Tomé & 0 & $\bullet$ & \\
Pagalu & $\triangle$ & & \\
\hline
\end{tabular}

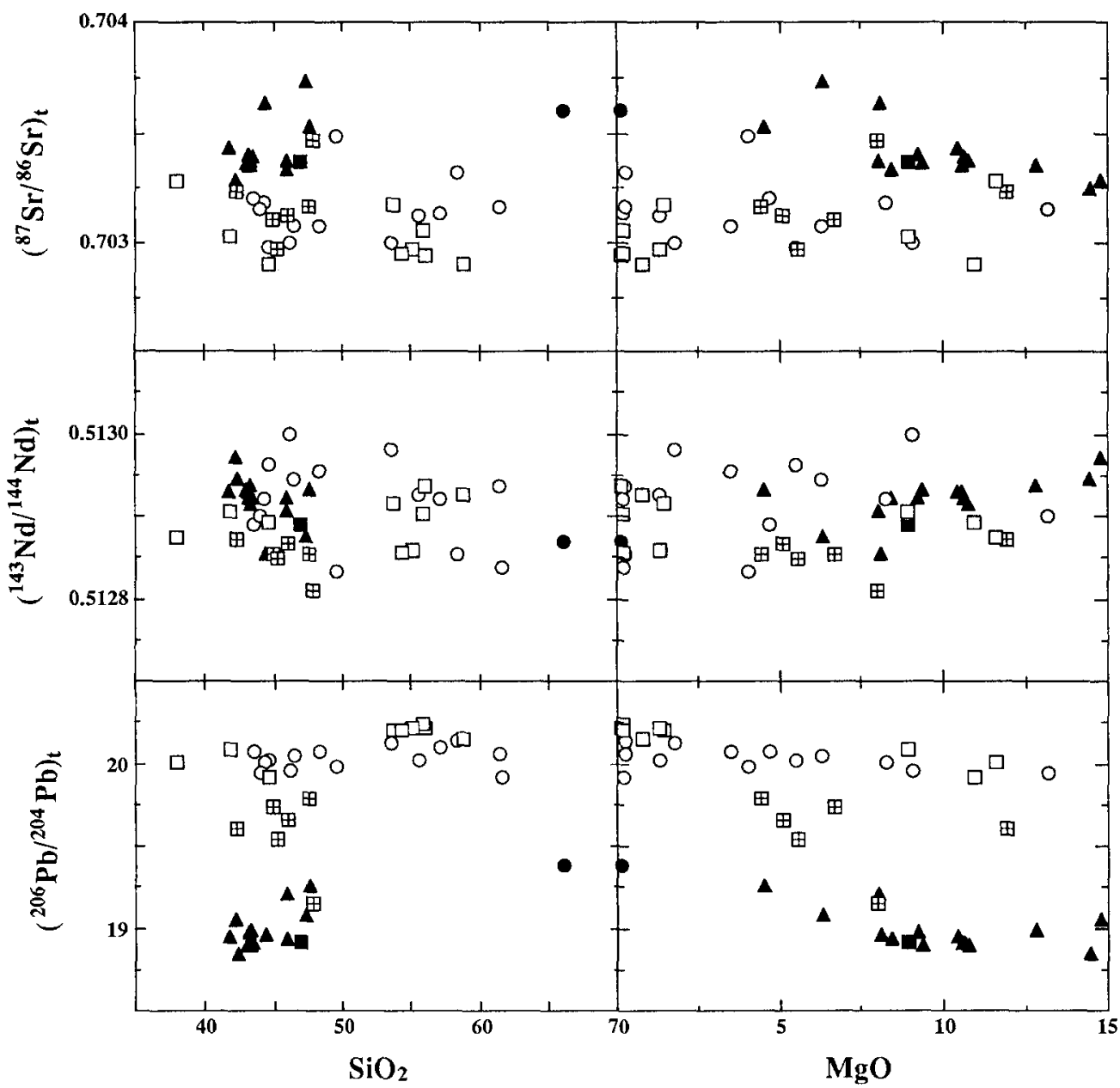

Fig. 6. Plots of $\mathrm{SiO}_{2}$ and $\mathrm{MgO}$ versus initial $\mathrm{Sr}, \mathrm{Nd}$ and $\mathrm{Pb}$ isotopic ratios for samples from the oceanic sector of the Cameroon line. Additional data are taken from $[2,32]$. 


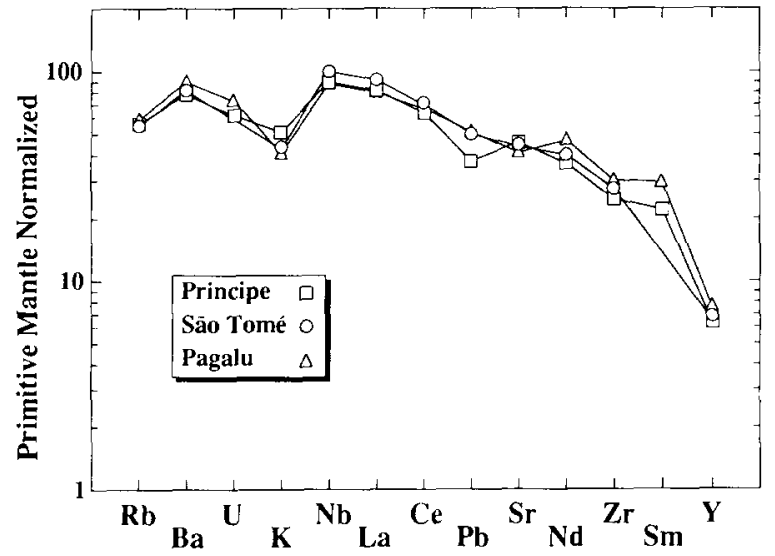

Fig. 7. Primitive mantle normalized trace element plot for selected samples ( $<10 \mathrm{Ma}$ and $\geqslant 4 \mathrm{wt} \% \mathrm{MgO}$ ) from Principe, Săo Tomé and Pagalu. The normalizing values are taken from [42].

Pagalu source, which is responsible for the overall isotopic variations in the oceanic sector of the Cameroon line (Figs. 4 and 5), the plume head or its derivative magmas interacted with both a depleted MORB mantle and an enriched mantle component during ascent. This process of admixing is probably caused by plume entrainment or is a diffusion-dominated chromatographic effect [46] and affects only trace elements, since there is a lack of systematic relationship between major elements and isotopic compositions (Fig. 6). Mixing processes at shallow depths, as proposed for the Canary Islands [17], where a correlation between isotope geochemistry and major element composition is observed, appear to be irrelevant in the case of the Cameroon line.

The observed mixing trends in Fig. 9 can be modeled by melting different proportions of two principle 'components', a HIMU and a second 'component' consisting of DMM-EMI mixtures. The average proportion of DMM to EMI in the second component does not appear to vary with time or between different islands, as can be seen from Fig. 9. However, the degree of homogeneity of the DMM-EMI mix does vary. Furthermore, the $\mathrm{Pb}$ in this DMM-EMI mixture appears to be more thoroughly homogenized than the $\mathrm{Nd}$ and Sr. Mixing variable amounts of HIMU and this mixed DMM-EMI component may account for the overall mixing between HIMU and the Pagalu source, and the parallel DMM-EMI mixing trends. Partial melting of an active plume head with HIMU signatures and entrained DMM-EMI ambient mantle may account for the observed isotopic variations in these islands. An active plume origin is consistent with the space-time distribution of the earliest magmatism in the oceanic sector of the Cameroon line. However, these islands are unlikely to originate from the same mantle plume, since each island seems to record different degrees of DMM-EMI homogeneity. This problem can be resolved if each island is supplied by an individual plume that shares a common origin. A single active plume model also encounters other difficulties, as is discussed further below.
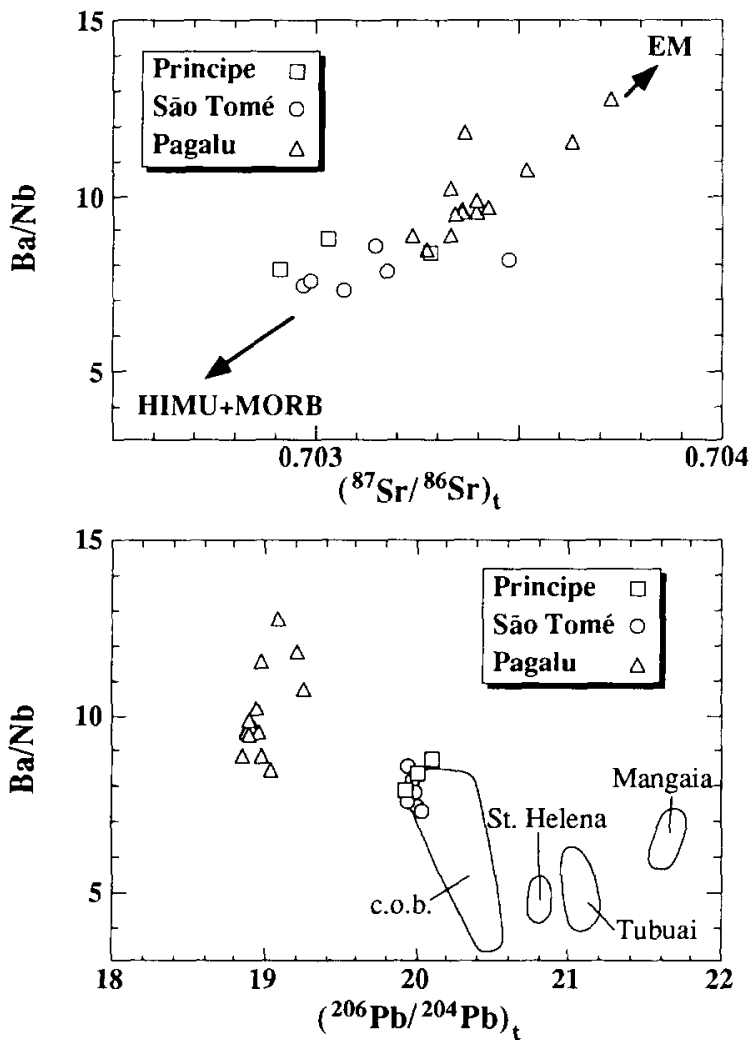

Fig. 8. Plots of initial ${ }^{87} \mathrm{Sr} /{ }^{86} \mathrm{Sr}$ and ${ }^{206} \mathrm{~Pb} /{ }^{204} \mathrm{~Pb}$ ratios versus $\mathrm{Ba} / \mathrm{Nb}$ ratios for the same samples used in Fig. 7. Additional data are taken from $[1,2,32,43-45]$. 
Regardless of the complexity of these mixing schemes, the isotopic variations in the oceanic sector of the Cameroon line fall within an area explicable through mixing of a depleted MORB mantle (DMM), an enriched mantle (EMI) and a HIMU mantle component (Fig. 9). The origin of DMM is most obvious, and probably reflects ambient MORB source upper mantle entrained with the rising plume [47-50]. The origin of EMI can be attributed to incorporation of ancient pelagic sediments in the source $[44,45]$ or delaminated subcontinental lithosphere $[17,18]$. The origin of HIMU mantle [7,43-45] is generally considered to involve sources with elevated $\mathrm{U} / \mathrm{Pb}$ ratios, relative to the bulk Earth, that have been isolated for a long period of time (e.g. $2 \mathrm{Ga}$ ). Therefore, the HIMU component is likely to originate in deeper mantle (e.g., the $670 \mathrm{~km}$ boundary layer), or deeper.

Halliday et al. [2,31] proposed that a plume was emplaced beneath the c.o.b. of the Cameroon line and coupled with the lithosphere at $125 \mathrm{Ma}$. The observed spatial variations in $\mathrm{Pb}$ isotopic ratios in the c.o.b. resulted from fractionation of $\mathrm{U} / \mathrm{Pb}$ during compaction and melting of the enriched plume head, increasing laterally toward the center of the plume head. According to the model, Principe, which is closer to the c.o.b., should be more radiogenic than Pagalu. This is true for the young lavas, but the $31 \mathrm{Ma}$ Principe sample has the same isotopic compositions as the Pagalu samples. The difficulty with this fossil plume model is that it provides no mechanism for melting, no explanation for why the earliest vol-
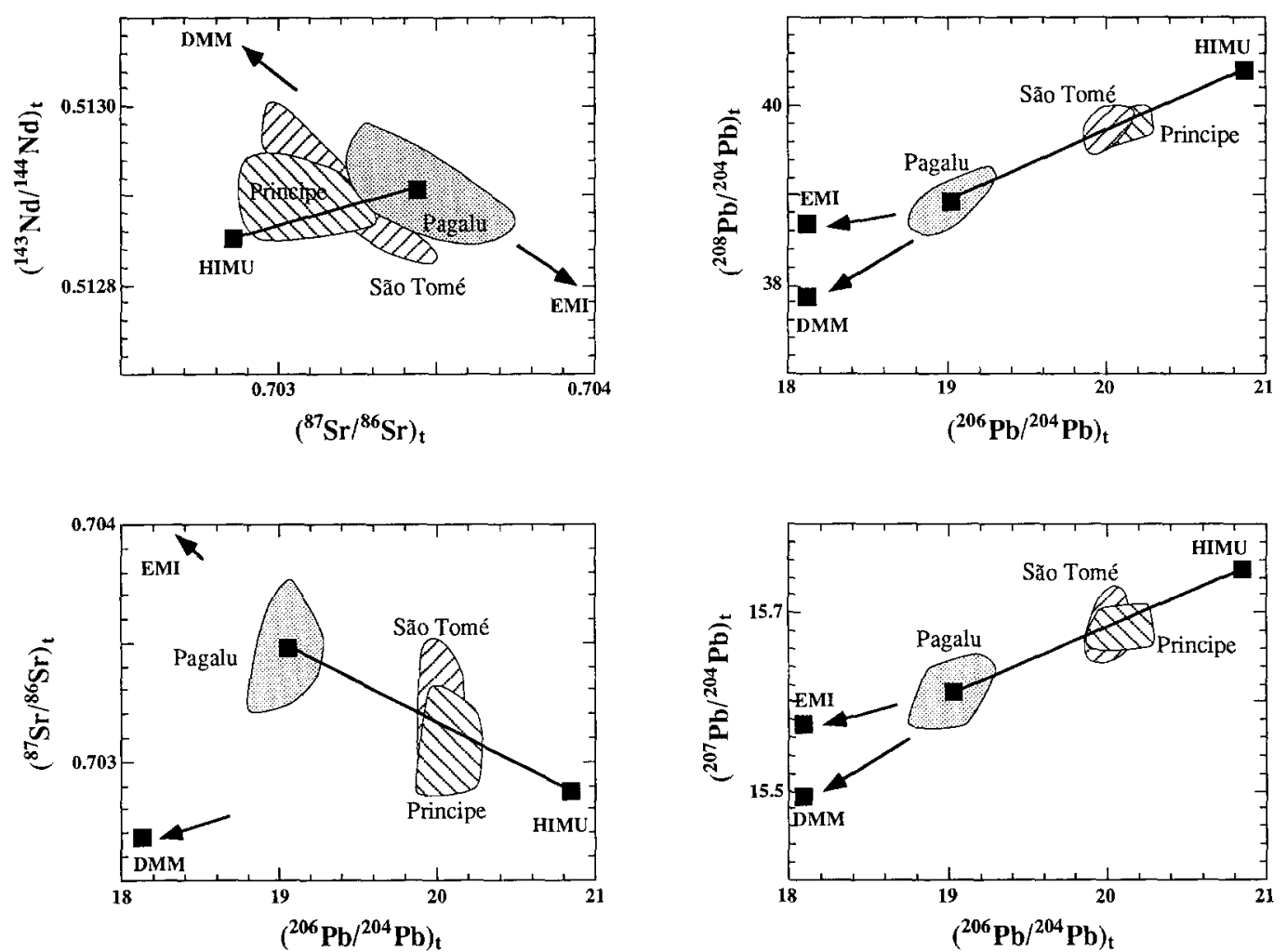

Fig. 9. Three-component mixing schemes for $<10 \mathrm{Ma}$ samples from each volcanic island. The solid lines connecting HIMU and Pagalu represent the overall mixing schemes found in these islands. The arrows, however, reflect the isotopic variations within individual island that can be modeled by incomplete mixing of DMM and EMI. Note that the $\mathrm{Pb}$ is more thoroughly mixed than $\mathrm{Sr}$ and $\mathrm{Nd}$. 
Sub-lithospheric"hot zone", the actual size and shape of which is unknown.
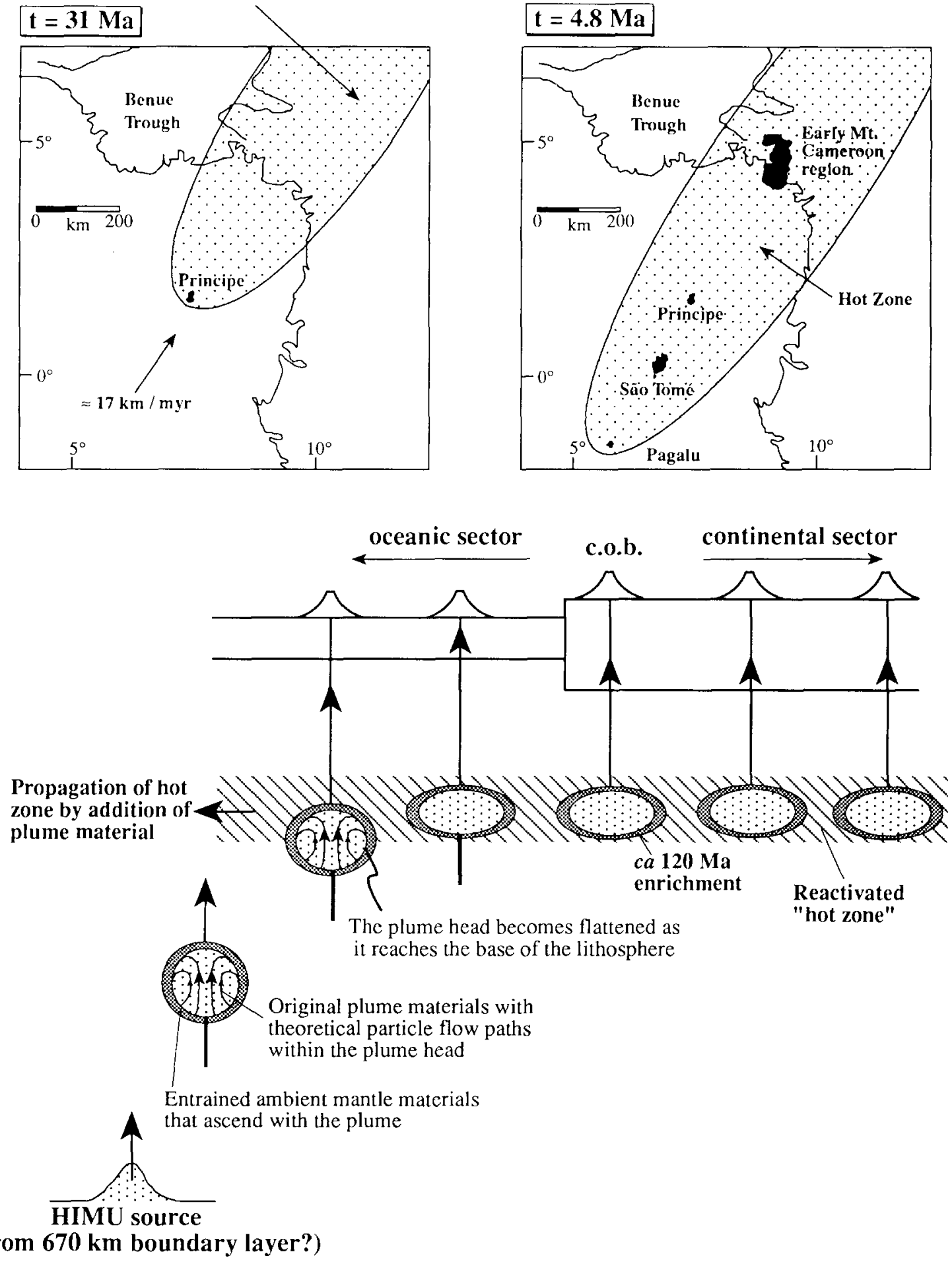
canism should always be associated with the most depleted source compositions and no prediction that the earliest volcanism should migrate from Principe to São Tomé to Pagalu. The temporal variations in isotopic composition observed in Principe and Sāo Tomé, however, could suggest that the fossil plume head was zoned vertically and is being tapped at different depths with time.

An alternative model is that an active plume, initiated in the deep mantle, with isotopic signatures of HIMU mantle, is currently expanding and extending its influence away from the c.o.b. This is consistent with the space-time distribution of the earliest volcanic activity in these volcanic islands. The plume head gradually flattened out when it reached the lithosphere and entrained some ambient mantle during its ascent [47-50]. Since this ambient mantle component, a mixture of DMM and EMI in this case, is concentrated around the margin of this plume head, early magmas that are produced due to decompression partial melting should mainly feature this ambient mantle component. As the plume rises further, original plume materials gradually become dominant in subsequent magmas. Although this active plume model offers a simple explanation for the data, it is in conflict with other observations. There is no systematic progression in the ages of volcanism for the rest of the Cameroon line [1] and the magma conduits must somehow remain coupled with the lithosphere for the past 30 myr. The Cameroon line is linear rather than circular in outline, as might be expected from a very large active plume head. In addition, this model cannot explain the relative enrichment of ${ }^{206} \mathrm{~Pb} /{ }^{204} \mathrm{~Pb}$ but not ${ }^{207} \mathrm{~Pb} /{ }^{204} \mathrm{~Pb}$ in the basaltic lavas from the c.o.b., which is explained by the source region evolving with high $\mathrm{U} / \mathrm{Pb}$ for ca. 125 myr [2]. Furthermore, the model does not explain the older (30-65 Ma) plutonic activity in the continental sector. Finally, the model does not predict the relationship between the locus of magmatism and African plate motion.

A new model is proposed which attempts to accommodate all of these features of the Cameroon line. We propose that the Cameroon line originates from a sublithospheric enriched 'hot zone', periodically fed and melted by deep mantle plumes (Fig. 10). Part of this zone of hotter mantle represents reactivated mantle previously enriched during the breakup of the South Atlantic in the Mesozoic. The observed $\mathrm{Pb}$ isotope anomaly of the basaltic lavas at the c.o.b. provide a record of this enrichment event. The earliest erupted magmas were in the continental sector (>35 Ma) and we suggest that the Cameroon line has been gradually expanding oceanward with time, while remaining active over considerable periods of time at any individual volcanic center. The focus of magmatism is, therefore, partly controlled tectonically; that is, by preferential flow paths through the lithosphere. As pointed out earlier, reconstructing the motion of the African plate indicates that the earliest volcanism of the Cameroon line volcanic islands (31 Ma for Principe; $\geqslant 13 \mathrm{Ma}$ for São Tomé; and 4.8 Ma for Pagalu) were all initiated from roughly the same location. In other words, the source region of the Cameroon line magmas in this region has been decoupled from the motion of the African plate and is located in the deep mantle. The observed spatial and temporal isotopic variations therefore reflect a combination of the horizontal heterogeneities within this hot zone and new plume material added from the deep mantle. The best way to reconcile the $\mathrm{Pb}$ isotope anomaly at the c.o.b. with an enrichment

\footnotetext{
Fig. 10. Sublithospheric 'hot zone' model. A sublithospheric hot zone, enriched since the late Mesozoic, has been periodically fed and melted by the addition of deep mantle plumes. A plume triggered the first eruption in Principe at ca. $31 \mathrm{Ma}$. Since then, the African plate has rotated counter-clockwise about a pole near the Azores [40]. The first eruptions of São Tomé ( $\geqslant 13 \mathrm{Ma}$ ) and Pagalu (4.8 Ma) were produced by partial melting of plume material from the same source as formed the lavas of Principe at 31 $\mathrm{Ma}$, due to the rotation of the African plate. These first eruptions in each island featured partial melting of entrained ambient mantle with isotopic signatures similar to Pagalu. The later magmas from the islands of Principe and São Tomé featured melting of original plume materials, dominated by HIMU isotopic signatures.
} 
that is roughly correlated to the earlier formation of the continental margin and the extended volcanic eruptions within each volcanic center, is if the Cameroon line is tapping sources that are both coupled and decoupled from the lithosphere (Fig. 10). This cannot be explained by the lithosphere controlling the nature of heterogeneities being sampled from the asthenosphere, for the alkali basalts at the c.o.b. are no more enriched, chemically, than other parts of the Cameroon line. It is still unclear how a plume becomes coupled with the lithosphere and remains active for as long as 30 myr. However, we speculate that the original plume component, HIMU, is probably the only part of this gradually rising, flattening and cooling plume head that is still hot enough to generate partial melting after long periods $\left(10^{7}\right.$ yr) of apparent quiescence.

Ascending mantle plumes are often driven by buoyancy, resulting from viscosity contrast. Therefore, they most likely originate from thermal boundary layers, for example, the core-mantle boundary or $670 \mathrm{~km}$ transition zone. Plumes originating from the core-mantle boundary are thought to be more voluminous, over $500 \mathrm{~km}$ in diameter, having ascended a much greater distance [47-49]. This is inconsistent with the small scales required for the Cameroon line. The more plausible plume source for the Cameroon line is, therefore, the $670 \mathrm{~km}$ transition zone. Our model differs significantly from those proposed for large systems such as Hawaii, in that several small plumes are involved. Furthermore, the concept of a buoyant, continuously replenished sublithospheric hot zone finds no parallel in the Hawaiian chain, where successive islands become dormant rapidly without reactivation. Therefore, the degree to which 'Cameroon line type' plume tectonics can be applied to other systems is unclear.

\section{Acknowledgments}

The manuscript was greatly improved by comments of G. Davies, E. Essene, M. Gurnis and S. Mukasa and reviews of S.R. Hart, K.A. Hoernle and an anonymous reviewer. C. Hall, M. Johnson and R. Keller are thanked for their technical assistance. This paper was supported by NSF Grants EAR 89-15936 and EAR 92-05435 to A.N. Halliday.

\section{References}

[1] J.G. Fitton and H.M. Dunlop, The Cameroon line, West Africa and its bearing on the origin of oceanic and continental alkalic basalt, Earth Planet. Sci. Lett. 72 , 23-38, 1985.

[2] A.N. Halliday, J.P. Davidson, P. Holden, C.P. DeWolf, D.-C. Lee and J.G. Fitton, Trace-element fractionation in plume and the origin of HIMU mantle beneath the Cameroon line, Nature 347, 523-528, 1990.

[3] H.M. Dunlop and J.G. Fitton, A K-Ar and Sr-isotopic study of the volcanic island of Principe, West Africaevidence for mantle heterogeneity beneath the Gulf of Guinea, Contrib. Miner. Petrol. 71, 125-131, 1979.

[4] S.R. Hart and A. Zindler, Constraints on the nature and development of chemical heterogeneities in the mantle, in: Mantle Convection, W.R. Peltier, ed., pp. 261-387, Gordon and Breach, New York, 1989.

[5] S.R. Hart, D.C. Gerlach and W.M. White, A possible new $\mathrm{Sr}-\mathrm{Nd}-\mathrm{Pb}$ mantle array and consequences for mantle mixing, Geochim. Cosmochim. Acta 50, 1551-1557, 1986.

[6] W.M. White, Sources of oceanic basalts: Radiogenic isotope evidence, Geology 13, 115-118, 1985.

[7] A. Zindler and S.R. Hart, Chemical geodynamics, Annu. Rev. Earth Planet. Sci. 14, 493-571, 1986.

[8] C.-Y. Chen and F.A. Frey, Origin of Hawaiian tholeiite and alkalic basalt, Nature 302, 785-789, 1983.

[9] C.-Y. Chen and F.A. Frey, Trace element and isotopic geochemistry of lavas from Haleakala Volcano, East Maui, Hawaii: implications for the origin of Hawaiian basalts, J. Geophys. Res. 90, 8743-8768, 1985.

[10] M.D. Kurz, M.O. Garcia, F.A. Frey and P.A. O'Brien, Temporal helium isotopic variations within Hawaiian volcanoes: basalts from Mauna Loa and Haleakala, Geochim. Cosmochim. Acta 51, 2905-2914, 1987.

[11] M.D. Kurz and D.P. Kammer, Isotopic evolution of Mauna Loa volcano, Earth Planet. Sci. Lett. 103, 257-269, 1991.

[12] H. Staudigel, A. Zindler, S.R. Hart, T. Leslie, C.-Y. Chen and $\mathrm{D}$. Clague, The isotope systematics of a juvenile intraplate volcano: $\mathrm{Pb}, \mathrm{Nd}$, and $\mathrm{Sr}$ isotope ratios of basalts from Loihi Seamount, Hawaii, Earth Planet. Sci. Lett. 69, 13-29, 1984.

[13] P. Stille, D.M. Unruh and M. Tatsumoto, Pb, $\mathrm{Sr}, \mathrm{Nd}$ and Hf isotopic evidence of multiple sources for Oahu, Hawaii basalts, Nature 304, 25-29, 1983.

[14] C.E. Hedge, Z.E. Peterman and W.R. Dickinson, Petrogenesis of lavas from Western Samoa, Geol. Soc. Am. Bull. 83, 2709-2714, 1972. 
[15] J.H. Natland, The progression of volcanism in the Samoan linear volcanic chain, Am. J. Sci. 280-A, 709-735, 1980.

[16] W.M. White and A.W. Hofmann, Sr and Nd isotope geochemistry of oceanic basalts and mantle evolution, Nature 196, 821-825, 1982.

[17] K.A. Hoernle, G.R. Tilton and H.U. Schmincke, Sr-Nd$\mathrm{Pb}$ isotopic evolution of Gran Canaria: evidence for shallow enriched mantle beneath the Canary Islands, Earth Planet. Sci. Lett. 106, 44-63, 1991.

[18] K.A. Hoernle and G.R. Tilton, $\mathrm{Sr}-\mathrm{Nd}-\mathrm{Pb}$ isotope data for Fuerteventura (Canary Islands) basal complex and subaerial volcanics: applications to magma genesis and evolution, Schweiz. Mineral. Mitt. 71, 3-18, 1991.

[19] R.C. Mitchell-Thomé, Geology of the South Atlantic Islands, Borntraeger, Berlin, 1970.

[20] J.G. Fitton, The Cameroon line, West Africa: a comparison between oceanic and continental alkaline volcanism, in: Alkaline Igneous Rocks, J.G. Fitton and B.G.J. Upton, eds., Geol. Soc. London Spec. Publ. 30, 273-291, 1987.

[21] B. Déruelle, C. Moreau, C. Nkoumbou, R. Kambou, J. Lissom, E. Njonfang, R.T. Ghogomu and A. Nono, The Cameroon line: a review, in: Magmatism in Extentional Structure Settings: the Phanerozoic African Plate, A.B. Kampunzu and R.T. Lubala, eds., pp. 275-327, Springer, Berlin, 1991.

[22] H. Jacquemin, J. Gouhier, W. Brown and I. Parsons, Les associations minérals du complexe anorogénigue de Mboutou (Nord Cameroun), C.R. Acad. Sci. Paris 292, 203-206, 1981.

[23] H. Jacquemin, S.M.F. Sheppard and P. Vidal, Isotopic geochemistry $(\mathrm{O}, \mathrm{Sr}, \mathrm{Pb})$ of the Golda Zuelva and Mboutou anorogenic complexes, North Cameroon: mantle origin with evidence for crustal contamination, Earth Planet. Sci. Lett. 61, 97-111, 1982.

[24] I. Parsons, W.L. Brown and H. Jacqcuemin, Mineral chemistry and crystallization conditions of the Mboutou layered gabbro-syenite-granite complex, North Cameroon, J. Petrol. 27, 1305-1330, 1986.

[25] B. Déruelle, C. Moreau and E.N. Nsifa, Sur la récente éruption du Mont Cameroun (16 octobre-12 novembre 1982), C.R. Acad. Sci. Paris 296, 807-812, 1983.

[26] J.G. Fitton, C.R.J. Kilburn, M.F. Thirlwall and D.J. Hughes, 1982 eruption of Mt. Cameroon, West Africa, Nature 306, 327-332, 1983.

[27] S.J. Freeth, Deformation of the African plate as a consequence of membrane stress domains generated by postJurassic drift, Earth Planet. Sci. Lett. 45, 93-104, 1979.

[28] F.B. Van Houten, Sirte Basin, north-central Libya: Cretaceous rifting above a fixed mantle hotspot? Geology 11, $115-118,1983$.

[29] W.J. Morgan, Hotspot tracks and the early rifting of the Atlantic, Tectonophysics 94, 123-139, 1983.

[30] C. Moreau, J.-M. Regnoult, B. Déruelle and B. Robineau, A new tectonic model for the Cameroon line, Central Africa, Tectonophysics 139, 317-334, 1987.
[31] A.N. Halliday, G.R. Davies, D.-C. Lee, S. Tommasini, C.R. Paslick, J.G. Fitton and D.E. James, Lead isotope evidence for young trace element enrichment in the oceanic upper mantle, Nature 359, 623-627, 1992 (Correction, Nature 362,184 ).

[32] A.N. Halliday, A.P. Dickin, A.E. Fallick and J.G. Fitton, Mantle dynamics: a $\mathrm{Nd}, \mathrm{Sr}, \mathrm{Pb}$ and $\mathrm{O}$ isotopic study of the Cameroon line volcanic chain, J. Petrol. 29, 181-211, 1988.

[33] J.G. Fitton and D.J. Hughes, Petrochemistry of the volcanic rocks of the island of Principe, Gulf of Guinea, Contrib. Mineral. Petrol. 64, 257-272, 1977.

[34] J.D. Hedberg, A geological analysis of the Cameroon Trend, Ph.D. Thesis, Princeton Univ, (unpublished), 1968.

[35] H.R. Grunau, P. Lehner, M.R. Cleintuar, P. Allenbach and $G$. Bakker, New radiometric ages and seismic data from Fuerteventura (Canary Islands), Maio (Cape Verde Island) and São Tomé (Gulf of Guinea), in: Progress in Geodynamics, G.J. Borradaile, A.R. Ritsema, H.E. Rondeel and O.J. Simon, eds., pp. 90-118, North-Holland, Amsterdam, 1975.

[36] G. Cornen and R.C. Maury, Petrology of the volcanic island of Annobon, Gulf of Guinea, Mar. Geol. 36, 253-267, 1980.

[37] J.M. Liotard, C. Dupuy, J. Dostal and G. Cornen, Geochemistry of the volcanic island of Annobon, Gulf of Guinea, Chem. Geol. 35, 115-128, 1982.

[38] J.D.A. Piper and A. Richardson, The paleomagmatism of the Gulf of Guinea volcanic province, West Africa, Geophys. J.R. Astron. Soc. 29, 147-171, 1972.

[39] A.W. Hofmann and W.M. White, Ba, Rb and $\mathrm{Cs}$ in the Earth's mantle, Z. Naturforsch. 38a, 256-266, 1983.

[40] F.F. Pollitz, Two-stage model of African absolute motion during the last 30 million years, Tectonophysics 194, 91-106, 1991.

[41] J.M. O'Connor and A.P. Ie Roex, South Atlantic hot spot-plume systems: 1 . Distribution of volcanism in time and space, Earth Planet. Sci. Lett. 113, 343-364, 1992.

[42] S.-S. Sun and W.F. McDonough, Chemical and isotopic systematics of oceanic basalts: implications for mantle composition and processes, in: Magmatism in the Ocean Basins, A.D. Saunders and M.J. Norry, eds., Geol. Soc. London Spec. Publ. 42, 315-345, 1989.

[43] Z.A. Palacz and A.D. Saunders, Coupled trace element and isotope enrichment in the Cook-Austral-Samoa Islands, S.W. Pacific, Earth Planet. Sci. Lett. 79, 270-280, 1986.

[44] C. Chauvel, A.W. Hofmann and P. Vidal, HIMU-EM: The French Polynesian connection, Earth Planet. Sci. Lett. 110, 99-119, 1992.

[45] B.L. Weaver, The origin of ocean island basalt end-member compositions: trace element and isotopic constraints, Earth Planet. Sci. Lett. 104, 381-397, 1991.

[46] O. Navon and E. Stolper, Geochemical consequences of melt percolation: the upper mantle as a chromatographic column, J. Geol. 95, 285-307, 1987. 
[47] R.W. Griffiths, The dynamics of mantle thermals with constant buoyancy or anomalous internal heating, Earth Planet. Sci. Lett. 78, 435-446, 1986.

[48] R.W. Griffiths, The differing effects of compositional and thermal buoyancies on the evolution of mantle diapirs, Phys. Earth. Planet. Inter. 33, 304-317, 1986.

[49] R.W. Griffiths, M. Gurnis and G. Eitelberg, Holographic measurements of surface topography in laboratory models of mantle hotspots, Geophys. J. 96, 477-495, 1989.

[50] S.R. Hart, E.H. Hauri, L.A. Oschmann and J.A. Whitehead, Mantle plumes and entrainment: isotopic evidence, Science 256, 517-520, 1992.

[51] K.O. Emery and E. Uchupi, The Geology of the Atlantic Ocean, Springer, New York, 1984.
[52] J.-C. Sibuet and J. Mascle, Plate kinematic implications of Atlantic equatorial fracture zone trends, J. Geophys. Res. 83, 3401-3421, 1978.

[53] H.E. Newsom, W.M. White, K.P. Jochum and A.W. Hofmann, Siderophile and chalcophile element abundances in oceanic basalts, $\mathrm{Pb}$ isotope evolution and growth of the Earth's core, Earth Planet. Sci. Lett. 80, 299-313, 1986.

[54] S.-S. Sun, Lead isotopic study of young volcanic rocks from mid-ocean ridges, ocean islands and island arcs, Philos. Trans. R. Soc. London Ser. A 297, 409-445, 1980. 